\title{
Kineococcus radiotolerans Dps forms a heteronuclear Mn-Fe ferroxidase center that may explain the Mn-dependent protection against oxidative stress
}

\author{
Matteo Ardini ${ }^{\mathrm{a}, 1}$, Annarita Fiorillo ${ }^{\mathrm{a}, 1}$, Maria Fittipaldi ${ }^{\mathrm{c}}$, Simonetta Stefanini ${ }^{\mathrm{a}}$, Dante Gatteschi ${ }^{\mathrm{c}}$, \\ Andrea Ilari ${ }^{\mathrm{b}}$, Emilia Chiancone ${ }^{\mathrm{a}, \mathrm{b}, *}$ \\ a Department of Biochemical Sciences “A. Rossi Fanelli", "Sapienza" University of Rome, Pl. A. Moro 5, 00185, Italy \\ ${ }^{\mathrm{b}}$ CNR Institute of Molecular Biology and Pathology, Pl. A. Moro 5, 00185 Rome, Italy \\ c Department of Chemistry, University of Florence, Via della Lastruccia 3, 50019 Sesto Fiorentino (Fi), Italy
}

\section{A R T I C L E I N F O}

\section{Article history:}

Received 3 August 2012

Received in revised form 14 January 2013

Accepted 4 February 2013

Available online 8 February 2013

\section{Keywords:}

Kineococcus radiotolerans DNA-binding

protein from starved cell structure

Hetero-nuclear manganese-iron center

Manganese(II) redox cycling

Oxidative stress protection

\begin{abstract}
A B S T R A C T
Background: The ferroxidase center of DNA-binding protein from starved cells (Dps) is a major player in the iron oxidation/detoxification process that leads to a decreased reactive oxygen species production. The possible $\mathrm{Mn}$ (II) participation in this process has been studied in Dps from Kineococcus radiotolerans, a radiation-resistant bacterium with a high cytosolic Mn/Fe ratio and a high capacity to survive ionizing and stress conditions.

Methods: The X-ray structure of recombinant K. radiotolerans Dps loaded with Mn(II) has been solved at $2.0 \AA$ resolution. $\mathrm{Mn}$ (II) binding to K. radiotolerans Dps and its effect on Fe(II) oxidation have been characterized in spectroscopic measurements.

Results: In K. radiotolerans Dps, the Fe-Fe ferroxidase center can have a Mn-Fe composition. Mn(II) binds only at the high affinity, so-called A site, whereas Fe(II) binds also at the low affinity, so-called B site. The Mn-Fe and $\mathrm{Fe}-\mathrm{Fe}$ centers behave distinctly upon iron oxidation by $\mathrm{O}_{2}$. A site-bound $\mathrm{Mn}$ (II) or $\mathrm{Fe}(\mathrm{II})$ plays a catalytic role, while B site-bound $\mathrm{Fe}$ (II) behaves like a substrate and can be replaced by another Fe(II) after oxidation. When $\mathrm{H}_{2} \mathrm{O}_{2}$ is the $\mathrm{Fe}$ (II) oxidant, single electrons are transferred to aromatic residues near the ferroxidase center and give rise to intra-protein radicals thereby limiting $\mathrm{OH}^{*}$ release in solution. The presence of the Mn-Fe center results in significant differences in the development of such intra-protein radicals.

Conclusions: $\mathrm{Mn}(\mathrm{II})$ bound at the Dps ferroxidase center A site undergoes redox cycling provided the B site contains Fe.

General significance: The results provide a likely molecular mechanism for the protective role of Mn(II) under oxidative stress conditions as it participates in redox cycling in the hetero-binuclear ferroxidase center.
\end{abstract}

(c) 2013 Elsevier B.V. All rights reserved.

\section{Introduction}

The protective role played by Mn in bacteria under several growth conditions that lead to oxidative stress and the correlations that link $\mathrm{Mn}$ and $\mathrm{Fe}$, another essential metal, are known since many years. However, the underlying molecular mechanisms are still not fully understood [1]. Lactobacillus plantarum is an aerotolerant bacterium which grows on fermenting Mn-rich plant material and accumulates this metal up to millimolar concentrations. The ability of this bacterium to tolerate oxygen exposure despite the lack of superoxide dismutase was ascribed to the spontaneous formation of $\mathrm{Mn}$ (II) complexes with small cellular ligands, like phosphate and lactate, which

\footnotetext{
* Corresponding author at: Department of Biochemical Sciences “A. Rossi Fanelli", "Sapienza" University of Rome, Pl. A. Moro 5, 00185, Italy. Tel.: + 3906 49910761; fax: + 39064440062 .

E-mail address: emilia.chiancone@uniroma1.it (E. Chiancone).

${ }^{1}$ The two authors contributed equally to the work.
}

act in vitro as superoxide or hydrogen peroxide scavengers [2,3]. This contention was supported by the observation that in Staphylococcus aureus $\mathrm{Mn}$ (II) forms a complex with lactate and orthophosphate and that the metal oxidation state in such complexes is influenced by oxygenation of the cell $[4,5]$.

The linkage between Mn and Fe, which is key to the present work, was established in later studies on the regulation of Mn transport. In brief, the uptake of both metals is controlled by members of the ferric uptake regulator (Fur) and DtxR family which act as Fe(II)- and $\mathrm{Mn}(\mathrm{II})$-dependent transcriptional repressors, respectively [6,7]. In S. aureus and Escherichia coli, for example, the DtxR-like Mn(II) transporter, MntR, reduces transcription when the cellular Mn concentration is high. Interestingly, $\mathrm{Mn}(\mathrm{II})$ transport via MntR is controlled also by OxyR, in E. coli, and PerR, in S. aureus, which afford peroxide resistance and hence link $\mathrm{Mn}(\mathrm{II})$ transport to the level of reactive oxygen species (ROS) in the cell. In recent work on E. coli, the relevant $\mathrm{Mn}$ (II) transporter, $\mathrm{MntH}$, was found to support the growth of iron-deficient cells and to be induced strongly upon $\mathrm{H}_{2} \mathrm{O}_{2}$ stress [8]. 
Mn was suggested to substitute Fe in some key metalloenzymes to account for the fact that, in contrast to current belief, Mn does not protect peroxide-stressed cells by scavenging $\mathrm{H}_{2} \mathrm{O}_{2}$. Among the possible candidates, the Dps protein was mentioned, a shell-like 12 mer of the ferritin family that is induced during $\mathrm{H}_{2} \mathrm{O}_{2}$ stress and catalyzes $\mathrm{Fe}$ (II) oxidation at the ferroxidase center. Like all such centers, the Dps protein ferroxidase center is binuclear and typically binds two Fe ions with different affinities. Subsequently, oxidized iron is sequestered in the protein cavity thereby inhibiting the Fenton-mediated production of ROS $[9,10]$. The possible substitution of Fe by $\mathrm{Mn}$ at the ferroxidase-center was not investigated even though Dps was suggested to be involved in the protection of peroxide-stressed cells since Mn supplementation of the growth medium suppresses the marked growth defect of mutants lacking Dps, peroxidase and catalase [8].

These data inspired the present work which establishes for the first time that Mn binds at the ferroxidase center of Kineococcus radiotolerans Dps $(K r D p s)$ and that this ion undergoes redox cycling just as Fe. The choice of the system was suggested by the work of Daly and collaborators on the unusual $\gamma$ radiation-resistant bacterium Deinococcus radiodurans $[11,12]$. The $D$. radiodurans cytoplasm is characterized by high Mn concentrations and by low Fe levels such that the intracellular $\mathrm{Mn} / \mathrm{Fe}$ ratio is significantly larger than in radiation-sensitive bacteria ( 0.24 compared to 0.0072 in E. coli). In line with this finding, when Mn availability in the growth medium is limited, and hence active Mn transport and accumulation impaired, radiation-resistance is drastically decreased [11]. These observations, and the fact that the harmful effects of radiations are mediated primarily by ROS, led us to the same suggestion put forward by Archibald and Fridovich [2,3], namely that Mn prevents the iron-dependent ROS development by the spontaneous formation of complexes with small cellular ligands which act as catalytic ROS scavengers [12], a contention challenged by the work of Anjem et al. [8] just mentioned.

$K$. radiotolerans is a radiation-resistant bacterium and is characterized by a high cellular Mn concentration and a high $\mathrm{Mn} / \mathrm{Fe}$ ratio, just like $D$. radiodurans. The data presented here show that $\mathrm{Mn}$ (II) binds at the high affinity A site but not at the low affinity B site of the binuclear ferroxidase center of $\mathrm{KrDps}$, whereas $\mathrm{Fe}(\mathrm{II})$ can bind at both the A and B sites. Importantly, the experiments unveiled that A site-bound $\mathrm{Mn}$ (II) has a catalytic role and participates in the ferroxidation reaction, whereas $\mathrm{B}$ site-bound $\mathrm{Fe}(\mathrm{II})$ acts as a substrate and, after each ferroxidation cycle, can be displaced by another Fe(II).

The present findings are discussed also in the framework of recent discoveries on the formation of $\mathrm{Mn}-\mathrm{Fe}$ hetero-nuclear cofactors in Chlamydia trachomatis ribonucleotide reductase [13] and in the Dps-like protein of Sulfolobus solfataricus [14] whose catalytic centers closely resemble those of $\mathrm{KrDps}$.

\section{Materials and methods}

\subsection{Protein preparation}

A pET-11a vector plasmid (5600 bp) containing the Krad_4280 wild-type gene (513 bp) was purchased from GeneArt AG (Germany) and introduced into E. coli BL21 (DE3) competent cells (Invitrogen) by heat shock transformation. After protein induction, purification was carried out following the procedure described for Listeria innocua Dps (LiDps) [15] which comprises a heat shock step ( 8 min at $348 \mathrm{~K}$ ) followed by precipitation in ammonium sulfate $(60 \% \mathrm{w} / \mathrm{v})$ and further purification by ion-exchange chromatography.

All buffers used for $K$. radiotolerans (KrDps) purification contained $200 \mathrm{mM} \mathrm{NaCl}$ to avoid protein self-aggregation. Protein concentration, expressed on a 12 mer basis throughout, was determined spectrophotometrically at $280 \mathrm{~nm}$ using the molar extinction coefficients $1.98 \times 10^{5} \mathrm{M}^{-1} \mathrm{~cm}^{-1}$ for $K r D p s$ and $2.03 \times 10^{5} \mathrm{M}^{-1} \mathrm{~cm}^{-1}$ for LiDps [16] on the basis of a 12 mer molecular mass of $224.5 \mathrm{kDa}$ and $216 \mathrm{kDa}$, respectively. The metal content of the purified proteins, assessed by atomic absorption spectroscopy, was $\leq 0.55 \mathrm{Fe} / 12 \mathrm{mer}$ and $\leq 0.02 \mathrm{Mn} / 12 \mathrm{mer}$ for $\mathrm{KrDps}$ and $1.2 \mathrm{Fe} / 12 \mathrm{mer}$ and $0.02 \mathrm{Mn}(\mathrm{II}) / 12 \mathrm{mer}$ for LiDps. Unless otherwise stated, all experiments were carried out in $50 \mathrm{mM}$ MOPS-NaOH buffer, pH 7.4 containing $200 \mathrm{mM} \mathrm{NaCl}$.

The site-specific mutant $\mathrm{KrDps}(\mathrm{W} 56 \mathrm{~F})$, where Trp56 is mutated into Phe, namely the residue present in most Dps proteins, was obtained by means of the QuikChange Site-Directed Mutagenesis Kit (Stratagene). The mutagenesis procedure was made on the pET-11a plasmid containing the wt $\mathrm{KrDps}$ gene using the forward and reverse primers 5'-GGAACATTGTGGGCGAAAACTTCCGCGATCTGCATCTGCAGC TGG-3' and 5'-CAGCTGCAGATGCAGATCGCGGAAGTTTTCGCCCACAAT GTTCC-3', respectively. The construct was sequenced to confirm sequence integrity. $\mathrm{KrDps}(\mathrm{W} 56 \mathrm{~F}$ ) was purified as described for $\mathrm{KrDps}$. The $\mathrm{KrDps}$ (W56F) concentration was calculated using the molar extinction coefficient of $1.32 \times 10^{5} \mathrm{M}^{-1} \mathrm{~cm}^{-1}$ on the basis of a $12 \mathrm{mer}$ molecular mass of $224.5 \mathrm{kDa}$.

\subsection{Protein crystallization, data collection and data processing}

Crystallization experiments, carried out at $298 \mathrm{~K}$ by the hanging drop vapor diffusion method, yielded X-ray quality crystals in one week. For the crystallization trials, $24 \mathrm{Mn}(\mathrm{II}) / 12 \mathrm{mer}$ were added to $\mathrm{KrDps}$ at $\sim 10 \mathrm{mg} / \mathrm{ml}(44 \mu \mathrm{M})$. After dialysis against $20 \mathrm{mM}$ Tris- $\mathrm{HCl}$ at $\mathrm{pH} 7.5$, aliquots of the protein solution were mixed with an equal amount of reservoir solution containing 45\% v/v MPD (2-methyl2,4-pentanediol) and $0.1 \mathrm{M}$ Tris- $\mathrm{HCl}$ at $\mathrm{pH}$ 8.0. Well shaped crystals grew in one week and reached dimensions of $0.3 \times 0.2 \times 0.2 \mathrm{~mm}^{3}$. Crystals were mounted in nylon loops and flash-frozen by quick submersion into liquid $\mathrm{N}_{2}$ for transport to the synchrotron. Two single wavelength data sets $(\lambda=0.918 \AA$ ) were collected at $100 \mathrm{~K}$ from two $\mathrm{KrDps}$ crystals at the synchrotron radiation source in BESSY, Berlin, Germany, using a MAR 225 CCD detector. The data sets were processed separately with DENZO and scaled together with SCALEPACK [17]. The auto-indexing procedure indicates that crystals are rhombohedral. Based on the scaling procedure, crystals belong to the R3 space group with cell parameters: $\mathrm{a}=\mathrm{b}=150.47 \AA, \mathrm{c}=86.62 \AA$ and $\alpha=\beta=90^{\circ}, \gamma=120^{\circ}$. The data are $100 \%$ complete with an $R_{\text {merge }}$ value of $8.3 \%$ at $2.0 \AA$ resolution. The data statistics are reported in Table 1.

Table 1

Crystal parameters, data-collection and refinement statistics of $\mathrm{KrDps}$. Values in parentheses are for the highest resolution shell.

\begin{tabular}{ll}
\hline Crystal parameters and data scaling & \\
\hline Space group & $\mathrm{R} 3$ \\
Unit-cell parameters & \\
$\quad a(\AA)$ & 150.47 \\
$\quad b(\AA)$ & 150.47 \\
$\quad c(\AA)$ & 86.61 \\
No. of monomers in ASU & 4 \\
$<$ B $>$ for atomic model $\left(\AA^{2}\right)$ & 16.2 \\
Resolution ranges $(\AA)$ & $2.0-50.0(2.0-2.07)$ \\
Unique reflections & $49,300(4946)$ \\
Completeness (\%) & $100(100)$ \\
Redundancy & $16.7(14.6)$ \\
$\mathrm{R}_{\text {merge }}$ (\%) & $8.3(33.9)$ \\
$\chi^{2}$ b & $1.098(0.83)$ \\
$<\mathrm{I} / \mathrm{s}(\mathrm{I})>$ & $40.95(7.77)$ \\
& \\
Refinement and geometric parameters & \\
\hline Resolution ranges $(\AA)$ & $2.0-50.0(2.0-2.05)$ \\
$\mathrm{R}_{\text {crys }}(\%)$ & 19.61 \\
$\mathrm{R}_{\text {free }}(\%)$ & 23.22 \\
RMS (angles) & 1.15 \\
RMS (bonds) & 0.01 \\
Residues in core region of Ramachandran plot & $96.1 \%$ \\
Residues in allowed region of Ramachandran plot & $3.9 \%$ \\
\hline
\end{tabular}

\footnotetext{
${ }^{\text {a }} \mathrm{R}_{\text {merge }}=\mathrm{S}_{\mathrm{hkl}} \mathrm{S}_{\mathrm{i}} \mid \mathrm{I}_{\mathrm{i}}(\mathrm{hkl})-<\mathrm{I}(\mathrm{hkl})>\mathrm{l} / \mathrm{S}_{\mathrm{hkl}} \mathrm{S}_{\mathrm{i}} \mathrm{I}_{\mathrm{i}}(\mathrm{hkl})$ where $\mathrm{I}_{\mathrm{i}}(\mathrm{hkl})$ is the observation of the reflection $(\mathrm{hkl})$ and $<\mathrm{I}(\mathrm{hkl})>$ is the mean intensity of the (hkl) reflection.

b $\chi^{2}=\mathrm{S}_{\mathrm{ii}}\left(\left|\mathrm{I}_{\mathrm{ij}}(\mathrm{hkl})-<\mathrm{I}_{\mathrm{i}}(\mathrm{hkl})>\right|\right)^{2} /\left(\mathrm{s}_{\mathrm{i}}^{2} \mathrm{~N} /(\mathrm{N}-1)\right)$.
} 


\subsection{Structure solution and refinement}

The $K r D p s$ structure was solved by molecular replacement using as search model Mycobacterium smegmatis Dps 2 (MsDps2, PDB ID: 2Z90) since it displays $56 \%$ sequence identity with $\mathrm{KrDps}$ (calculated using the NCBI-BLAST server). The rotational and translational searches performed with MOLREP in the resolution range 10.0-3.0 Å produced a clear solution [18].

Refinement was performed using the maximum likelihood method with the program REFMAC including individual isotropic B-factor and TLS refinement [19], while model building was performed with the program COOT according to Emsley and Cowtan [20]. The final KrDps model is a tetramer containing 668 residues (167 residues for chain A, 169 residues for chains $B$ and $C$ and 166 residues for chain D), 10 $\mathrm{Mn}(\mathrm{II})$ ions (4 with full, 2 with $0.7,1$ with $0.5,2$ with $0.33,1$ with 0.15 occupancy), 6 chloride ions ( 5 with full and 1 with 0.33 occupancy) and 322 water molecules. The final $\mathrm{R}_{\text {crys }}$ for all resolution shells (50-2.0 ^) calculated using all 46,797 reflections is $19.6 \%$, and the free $\mathrm{R}$ value calculated using the 2491 test set reflections is $23.2 \%$. The final $\mathrm{R}_{\text {crys }}$ calculated for the highest resolution shell (2.05-2.0 $\mathrm{A}$ ) using the working set reflections (3411) is $23.9 \%$, and the free $\mathrm{R}$ value calculated using the test set reflections (203) is $29.0 \%$. The most favored regions of the Ramachandran plot contain $96.1 \%$ of the residues (Table 1 ).

The metal ions bound to the protein were identified by means of $\mathrm{X}$-ray fluorescence emission spectra collected at the BESSY synchrotron radiation source (Beamline BL-14.1) in an energy range between 2000 and $25,000 \mathrm{eV}$.

\section{4. $\mathrm{Fe}$ (II) and $\mathrm{Mn}$ (II) binding: anaerobic fluorescence titrations}

$\mathrm{Fe}(\mathrm{II})$ and $\mathrm{Mn}$ (II) binding to $\mathrm{KrDps}$ was followed by measuring the intrinsic protein fluorescence under anaerobiosis using a Fluoromax-4 spectrofluorometer (Horiba-Jobin Yvon). The excitation wavelength was $290 \mathrm{~nm}$, emission was recorded between 300 and $400 \mathrm{~nm}$ using $5 \mathrm{~nm}$ entry and exit slits. All measurements were carried out at $298 \mathrm{~K}$ under a $\mathrm{N}_{2}$ atmosphere in a gas tight, $1 \mathrm{~cm}$ path length cell under continuous stirring. Metals were added to a $2 \mu \mathrm{M}$ apo-KrDps protein solution in 4 ions/12mer increments. Fe(II) was added as an anaerobic $2.4 \mathrm{mM} \mathrm{Fe}\left(\mathrm{NH}_{4}\right)_{2} \mathrm{SO}_{4}$ solution in $1 \mathrm{mM} \mathrm{HCl}$. $\mathrm{Mn}$ (II) was prepared as an anaerobic $2.4 \mathrm{mM}$ solution in distilled water obtained by dilution of a standard solution (Fluka).

\subsection{Kinetics of $\mathrm{Fe}(\mathrm{II})$ oxidation by $\mathrm{O}_{2}$ : spectrophotometric assays}

The kinetics of $\mathrm{Fe}(\mathrm{II})$ oxidation by $\mathrm{O}_{2}$ was assessed spectrophotometrically on a 8452A Diode Array spectrophotometer (HewlettPackard). Fe oxidation was followed for $60 \mathrm{~min}$ by measuring the ferric hydrous oxide formed at $310 \mathrm{~nm}$. The amount of oxidized iron was calculated using the molar extinction coefficient, $\mathrm{E}_{\mathrm{M}}, 310 \mathrm{~nm}=$ $2528 \mathrm{M}^{-1} \mathrm{~cm}^{-1}$, reported in Ref. [15]. All experiments were performed at $298 \mathrm{~K}$ in a $1 \mathrm{~cm}$ path length cell on $6 \mu \mathrm{M} \mathrm{KrDps}$ maintained under continuous stirring in air. Mn(II), when present, was added to the protein solution $5 \mathrm{~min}$ before $\mathrm{Fe}(\mathrm{II})$ addition. $\mathrm{Fe}(\mathrm{II})$ and $\mathrm{Mn}$ (II) were prepared as $37.7 \mathrm{mM}$ solutions as described for the fluorescence experiments. The data were analyzed with Origin 8 PRO software (OriginLab, Northampton, MA, USA).

\subsection{Kinetics of $\mathrm{Fe}(\mathrm{II})$ oxidation by $\mathrm{H}_{2} \mathrm{O}_{2}$ : stopped-flow experiments}

Generation of transient intra-protein radical species upon oxidation of $\mathrm{Fe}(\mathrm{II})$ by $\mathrm{H}_{2} \mathrm{O}_{2}$ and the possible effect of $\mathrm{Mn}$ (II) were assessed in a stopped-flow apparatus equipped with a Spectra/kinetic monochromator (Applied PhotoPhysics). Experiments were performed at $298 \mathrm{~K}$ in a sequential mixing setup by recording absorbance spectra in the diode array mode between 350 and $700 \mathrm{~nm}$ every $3 \mathrm{~ms}$ for a total of $300 \mathrm{~ms}$. A $68 \mu \mathrm{M}$ protein solution in $200 \mathrm{mM}$ MOPS-NaOH,
pH 7.4 containing $800 \mathrm{mM} \mathrm{NaCl}$ was mixed with $400 \mu \mathrm{M} \mathrm{FeSO}{ }_{4}$ in $1 \mathrm{mM} \mathrm{HCl}$ and, after a $500 \mathrm{~ms}$ delay, with $100 \mu \mathrm{M} \mathrm{H} \mathrm{H}_{2} \mathrm{O}_{2}$ to obtain a final reaction mixture with a molar ratio of $6 \mathrm{Fe}(\mathrm{II}) / 12 \mathrm{mer}$ and 3 $\mathrm{H}_{2} \mathrm{O}_{2} / 12$ mer. A second set of experiments was performed using a protein solution pre-loaded with $12 \mathrm{Mn}(\mathrm{II}) / 12$ mer. For these experiments, $\mathrm{MnCl}_{2}$ was dissolved freshly in distilled water. In a third set, the protein solution was mixed with $800 \mu \mathrm{M} \mathrm{MnCl} 2$ and, after a 500 ms delay, with $100 \mu \mathrm{M} \mathrm{H}_{2} \mathrm{O}_{2}$ to achieve a molar ratio of 12 $\mathrm{Mn}(\mathrm{II}) / 6 \mathrm{H}_{2} \mathrm{O}_{2} / 12 \mathrm{mer}$. The data were analyzed with Origin 8 PRO (OriginLab, Northampton, MA, USA). To calculate the yield of tryptophan radical species the published molar coefficient extinction of $2300 \pm 150 \mathrm{M}^{-1} \mathrm{~cm}^{-1}$ was used [21].

\subsection{Sedimentation velocity experiments}

Sedimentation velocity experiments were carried out at 30,000 rpm and $293 \mathrm{~K}$ on a Beckman XLI analytical ultracentrifuge using absorbance optics. The experiments were conducted on a $4 \mu \mathrm{M}$ apo-KrDps solutions pre-soaked for $2 \mathrm{~h}$ with $240 \mathrm{Mn}$ (II) or $240 \mathrm{Fe}(\mathrm{II}) / 12 \mathrm{mer}$ in air or in the presence of $\mathrm{H}_{2} \mathrm{O}_{2}$ ( 0.5 equivalents relative to the metal). Radial absorbance scans were obtained at a spacing of $1.2 \mathrm{~cm}$ in a continuous scan mode; 3 subsequent scans were averaged. Sedimentation coefficients were calculated using the software SEDFIT (provided by Dr. P. Schuck, National Institutes of Health) and were reduced to water and $293 \mathrm{~K}$ $\left(\mathrm{s}_{20, \mathrm{w}}\right)$ by standard procedures.

\subsection{Electron paramagnetic resonance}

EPR (Electron Paramagnetic Resonance) spectra at X-band $(9.39 \mathrm{GHz})$ were recorded by using a Bruker Elexsys E500 spectrometer equipped with a continuous-flow ${ }^{4} \mathrm{He}$ cryostat (ESR 900, Oxford Instruments) to work at variable temperatures. The perpendicular-mode EPR spectra were acquired using a field modulation of $100 \mathrm{kHz}$ and $10 \mathrm{G}$, and a microwave power of $20.8 \mathrm{~mW}$ at $30 \mathrm{~K}$. Each sample was degassed, maintained under a $\mathrm{N}_{2}$ atmosphere and frozen immediately after addition of the metal. The ferrous ammonium sulfate and $\mathrm{Mn}$ (II) chloride solutions were prepared freshly, flushed with $\mathrm{N}_{2}$ and maintained in anaerobiosis.

\section{Results}

\subsection{X-Ray crystal structure of K. radiotolerans Dps}

Purified recombinant $\mathrm{KrDps}$ is essentially free of Fe and $\mathrm{Mn}(\leq 0.5$ $\mathrm{Fe} / 12 \mathrm{mer}$ and $\leq 0.02 \mathrm{Mn} / 12 \mathrm{mer}$ ) as determined by atomic absorption spectroscopy. To establish whether Mn binds at the ferroxidase center, $24 \mathrm{Mn}$ (II)/12mer were added to the protein solution prior to crystallization. The X-ray quality crystals obtained after one week diffracted to $2.0 \AA$ resolution. The $\mathrm{KrDps}$ X-ray structure was solved by molecular replacement using the tetramer of MsDps2 (PDB ID: $2 \mathrm{Z90}$ [22]) as search model since the two sequences are $56 \%$ identical (87/155 residues).

All known Dps proteins are shell-like 12mers of identical 4-helix bundle monomers related by 23 symmetry. Thus, two types of interface are defined at the 3-fold symmetry axes. The so-called "ferritin-like" interface is formed by the N-terminal portion of the subunits and corresponds to the 3-fold interactions in the ferritin polymer with 432 symmetry. The so-called "Dps-type" interface involves the C-terminal part of the symmetry-related subunits and is present only in Dps proteins [23]. At their junction, the 3-fold symmetry related subunits create channels of two kinds that allow ions and small molecules to traverse the protein shell and reach the internal cavity. The "ferritin-like" pores are rich in aspartate residues that give rise to a negative electrostatic gradient which drives iron in and out of the cavity [24]. The "Dps-type" pores, whose precise function has not been clarified, are characterized by a marked residue variability. 
In Dps proteins, the catalytic Fe(II) oxidation takes place at a bimetallic ferroxidase center, located at the interface between 2-fold symmetry related subunits. These furnish the metal ligands as revealed by the LiDps structure [23]. The two metal binding sites, called $\mathrm{A}$ and $\mathrm{B}$, have different metal affinities. Only the higher affinity A site usually contains iron in the known Dps crystal structures. This is the case of LiDps, where one iron ion is coordinated by Asp58 and Glu62 from one subunit, by His31 from the 2-fold symmetry-related one and by a water molecule that is hydrogen bonded to a second histidine (His43) from the latter subunit. This water molecule has been hypothesized to be replaced by the second iron atom and thereby give rise to the $\mathrm{B}$ site of a canonical bimetallic ferroxidase center [23]. The amino acids just mentioned are conserved in all Dps proteins $[25,26]$. In the crystal structures of $D$. radiodurans Dps2 [27] and Bacillus brevis Dps [28], both the A and B sites are occupied by iron, even though B site-bound iron is loosely coordinated. In E. coli Dps [29] and Thermosynechococcus elongatus Dps [30] both sites are occupied by a water molecule. This variability in iron occupancy suggests that the amino acid residues forming the second metal coordination shell influence the affinity for the metal.

The KrDps monomer displays the typical Dps 4-helix bundle fold. Superposition of the $\mathrm{KrDps}$ monomer structure (Fig. 1, magenta) on those of the E. coli Dps (EcDps) and MsDps2 monomers (blue and yellow, respectively) shows that the only differences concern the flexible parts, in particular the $\mathrm{N}$-terminus. The residues forming the three long N-terminal tails are mostly hydrophobic in $\mathrm{KrDps}$ and give rise to two $\alpha$-helical turns $(\alpha 0)$, but are mostly hydrophilic in EcDps and MsDps2 where they assume a random coil conformation. In the $\mathrm{KrDps} 12 \mathrm{mer}$, the $\mathrm{N}$-terminal $\alpha 0$ helix of one monomer interacts with the N-terminal part of the $\mathrm{C}$ helix of the 3-fold symmetry related monomer (Fig. 2A) by means of mainly hydrophobic interactions which involve the $\alpha 0$ helix residues, Ile4, Val7, Leu12, and Ala116 and Ala112 of the C helix (Fig. 2B).

The Fo-Fc electron density map shows a strong peak due to a heavy metal at the ferroxidase center. The assignment to Mn was based on the $\mathrm{X}$-ray fluorescence emission spectra of the $\mathrm{KrDps}$ crystal, since the most intense peaks (at 5.88, 5.89 and $6.49 \mathrm{keV}$ ) correspond to those of the Mn ion (Fig. S1, panel A). Mn is coordinated at the ferroxidase center A site by Asp75, Glu79 and His48 that correspond to the three canonical Fe ligands in Dps proteins [25,26], e.g. to Asp58, Glu62 and His31 in LiDps. All metal ion-ligand distances are between 2.0 and $2.2 \AA$. The Mn coordination geometry is bi-pyramidal (Fig. $3 \mathrm{~A}$ ). The equatorial ligands are Asp75, which ligates Mn(II) with both carboxylic oxygen atoms, His48 and a water molecule. The apical ligands are Glu79 and another water molecule (Fig. 3A). A comparison between the available Dps structures brings out that Lys45 and Asp64 play a specific role in metal binding to $\mathrm{KrDps}$ as they are hydrogen bonded to the metalcoordinating water molecule (data not shown). These two residues are conserved in many Dps proteins e.g. EcDps, the family prototype [29], and MsDps2 [22], but not in T. elongatus DpsA [31] and $D$. radiodurans Dps [32] where they are replaced by two Gln and by Lys and Gln, respectively. The KrDps metal ligands at the B site, Glu79 and His60, occupy the same position identified in LiDps [23]. Interestingly, His60 is hydrogen bonded to the water molecule which furnishes one of the apical Mn ligands ( $\mathrm{HOH}-\mathrm{NE} 2$ distance 2.8-3.1 A in the different monomers of the asymmetric unit). It may be hypothesized that binding of a metal at the B site displaces this water molecule and reorganizes the ferroxidase center accordingly [23].

The $\mathrm{KrDps}$ sequence is characterized by the unusual presence of three Trp residues (Fig. 3B). Two are conserved in all known Dps proteins, namely Trp49 and Trp158 (Trp32 and Trp144 in LiDps), and are located near the ferroxidase center. The additional Trp residue, Trp56, substitutes an otherwise conserved Phe. Trp56 is hydrogen bonded via its indolic ring nitrogen atom to the carbonyl oxygen of Ile51, is placed near Trp158 (minimal distance of $4.4 \AA$ ) and forms a stacking interaction with His60 (minimal distance of $3.6 \AA$ ), a proposed metal coordinating ligand at the ferroxidase center B site. Moreover, Trp56 is near to Asn55, one of the $\mathrm{Mn}$ (II) ligands at the metal binding sites along the "Dps-type" interface (see below).

The structure of $\mathrm{KrDps}$ loaded with $24 \mathrm{Mn}(\mathrm{II}) / 12$ mer shows $\mathrm{Mn}$ binding at sites other than the ferroxidase center. One is at the "ferritin-like" pore entrance and contains two pentacoordinated Mn
A

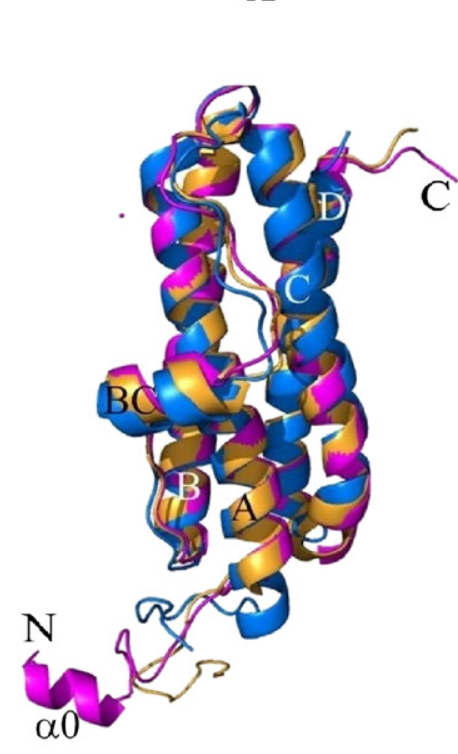

B

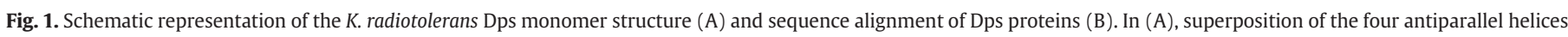

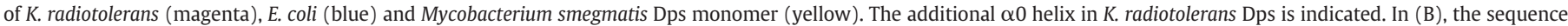

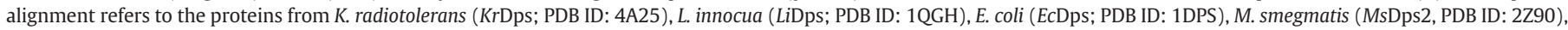

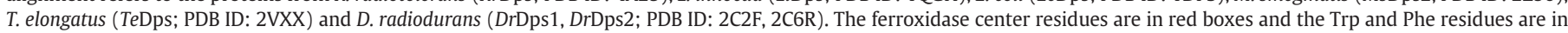
green boxes. The pictures were obtained with PyMol [40]. 
A

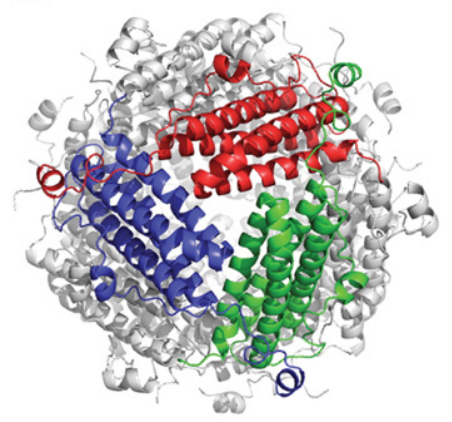

B

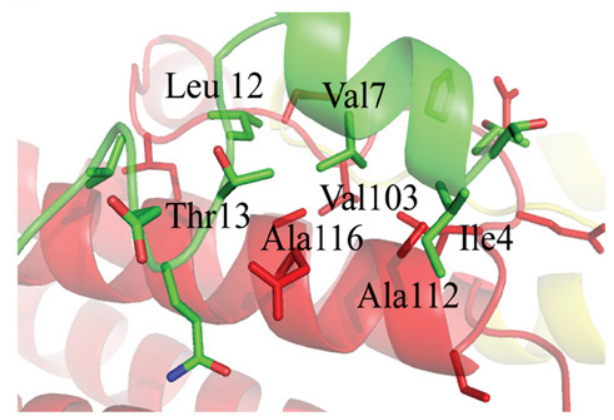

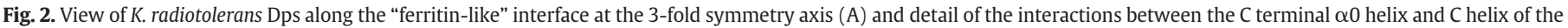
3-fold symmetry related monomer (B). Pictures were obtained with PyMol [40].

placed at a 3.4 A distance (Fig. S1, panel B). The Mn(II) closest to the pore entrance is coordinated by the OD1 atoms of Asp144 of the 3-fold symmetry-related subunits and by two water molecules, while the second $\mathrm{Mn}$ (II) is coordinated by the OD2 atoms of the same residues and by two water molecules. Metal binding at the "ferritin-like" pore entrance is not unexpected, since iron and other metals enter the protein cavity through this pore, and indeed have been observed in the crystal structure of several Dps proteins [32-34]. The other Mn site is at the "Dps-type" pore entrance, a location not described before to our knowledge. Mn bound at this interface is hexa-coordinated with a typical bi-pyramidal geometry (Fig. S1, panel C) and coordination distances between 2.0 and 2.1 A. The ligands are oxygen atoms belonging to Asn55 and Asp58 of the 3-fold symmetry related subunits.

In the Dps-like peroxide resistance protein from Streptococcus suis (SsDpr), one Mn ion was reported to bind at the ferroxidase center with a similar coordination as in $\mathrm{KrDps}$ [35]. However, no Mn binding was observed at the SsDpr "Dps-type" interface where Asn55 and Asp58, the metal ligands in $\mathrm{KrDps}$, are substituted respectively by Gly and Ile.

\subsection{Protein characterization in solution}

The additional Trp56 in $K r D p s$ impacts on the spectroscopic properties of the protein as evidenced by a comparison of the KrDps and KrDps(W56F) UV absorbance and near-UV CD spectra (Fig. S2).

In sedimentation velocity experiments, $\mathrm{KrDps}$ forms a single symmetrical, homogeneous peak characterized by a weight average sedimentation coefficient, $\mathrm{s}_{20, \mathrm{w}}$, of $10.5 \mathrm{~S}$, corresponding to a spherical molecule of $\sim 224.5 \mathrm{kDa}$ and a partial specific volume of 0.73 .

\section{3. $\mathrm{Mn}(\mathrm{II})$ and $\mathrm{Fe}(\mathrm{II})$ binding and incorporation properties}

In Dps proteins, $\mathrm{Fe}(\mathrm{II})$ binding to the ferroxidase center, due to its location at $<5 \AA$ from one highly conserved Trp residue (e.g. Trp32 in LiDps), has been followed by measuring quenching of the intrinsic protein fluorescence in anaerobiosis [36].

The same approach was applied to probe $\mathrm{Fe}(\mathrm{II})$ and $\mathrm{Mn}$ (II) binding at the ferroxidase center of KrDps. In a first set of titrations, $24 \mathrm{Fe}(\mathrm{II}) /$ 12 mer and $48 \mathrm{Mn}(\mathrm{II}) / 12 \mathrm{mer}$ were added in sequence to $2 \mu \mathrm{M} \mathrm{KrDps}$ as purified in 4 ions/12mer increments. As reported in Fig. $4 \mathrm{~A}$, fluorescence intensity decreases by $\sim 18 \%$ upon addition of $\sim 12 \mathrm{Fe}$ (II)/ 12 mer and by a further $5 \%$ after addition of the remaining $12 \mathrm{Fe}(\mathrm{II})$. The $5 \%$ decrease can be taken to indicate that $\mathrm{Fe}(\mathrm{II})$ binds to both the $A$ and $B$ sites of the ferroxidase center with different affinities, as reported for LiDps on the basis of ITC experiments [36]. Binding to Asn55 and Asp58 near the "Dps-type" pores would not be sensed as the closest Trp residue, Trp56, is at about $9 \AA$ from the A site. The subsequent addition of $48 \mathrm{Mn}$ (II) results in a small fluorescence recovery. In a second set of titrations, the order of Fe and Mn additions to $\mathrm{KrDps}$ was reversed. Fig. $4 \mathrm{~B}$ shows that the initial fluorescence intensity is quenched by $\sim 10 \%$ upon addition of $\sim 12 \mathrm{Mn}(\mathrm{II}) / 12 \mathrm{mer}$ and does not change significantly when other $12 \mathrm{Mn}(\mathrm{II}) / 12$ mer are added. Interestingly, the subsequent addition of $48 \mathrm{Fe}(\mathrm{II}) / 12$ mer leads to further, significant quenching. The final fluorescence intensity is $~ 10 \%$ lower relative to the value attained upon addition of $24 \mathrm{Fe}(\mathrm{II}) /$ $12 \mathrm{mer}$ (Fig. 4A). Based on the fluorescence data, the equilibrium dissociation constant, $\mathrm{K}_{\mathrm{D}}$, for $\mathrm{Mn}(\mathrm{II})$ and $\mathrm{Fe}(\mathrm{II})$ binding is respectively $\approx 8 \mu \mathrm{M}$ and $\approx 6.5 \mu \mathrm{M}$, as compared to a $\mathrm{K}_{\mathrm{D}}$ of $55 \mu \mathrm{M}$ for $\mathrm{Mn}$ (II) binding to SsDpr obtained by ITC [35]. Taken together, the fluorescence titration data indicate that Mn binds only to the high affinity A site
A

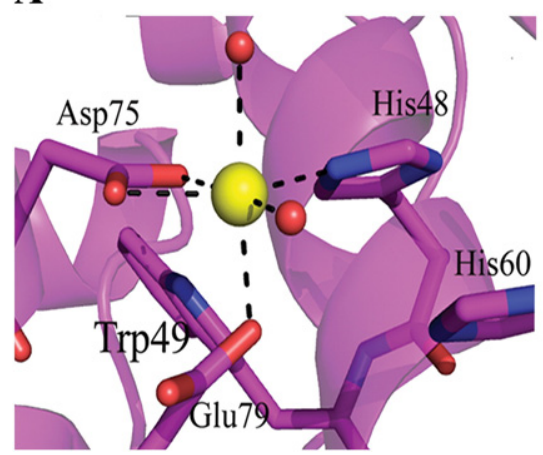

B

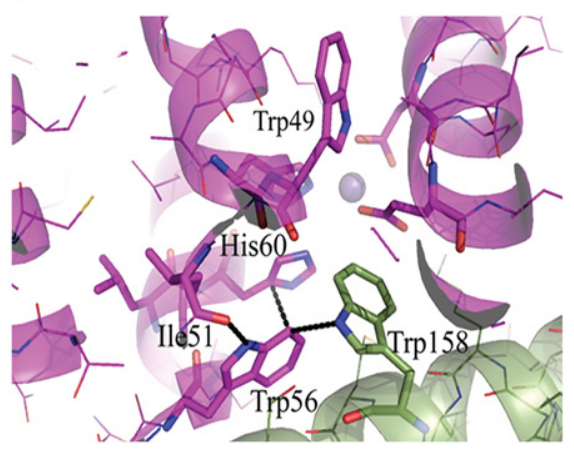

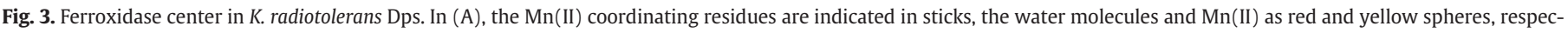

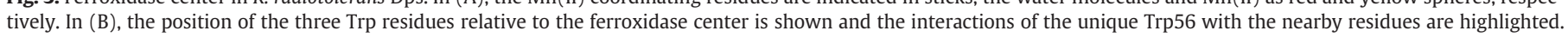
Pictures obtained with PyMol [40]. 

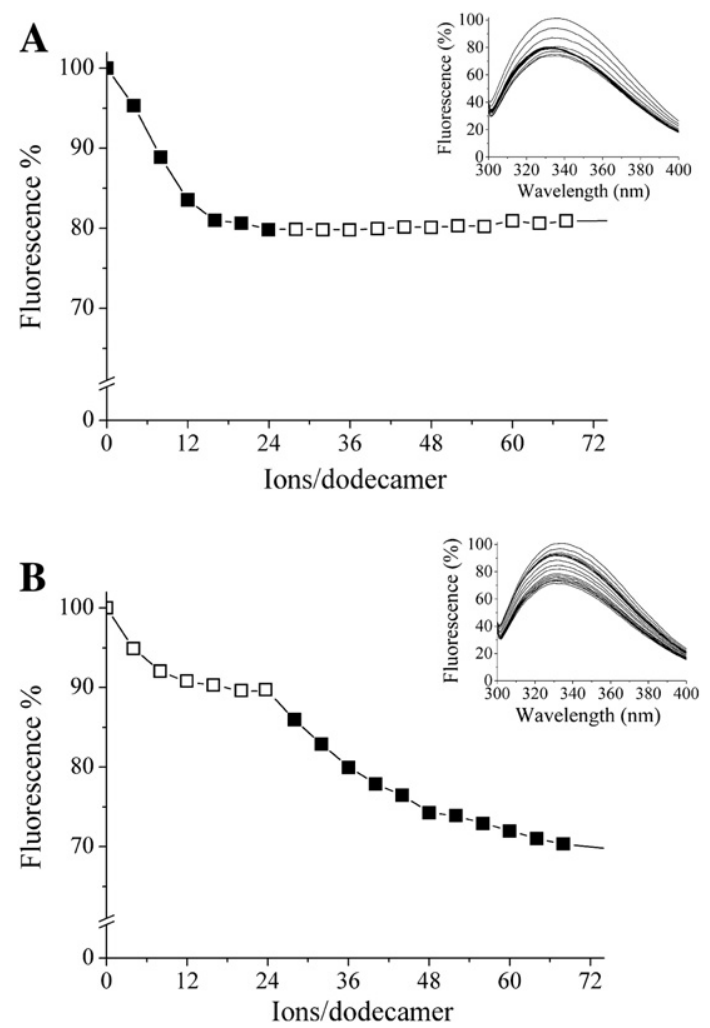

Fig. 4. Anaerobic fluorescence titration of K. radiotolerans Dps with $\mathrm{Fe}(\mathrm{II})$ and $\mathrm{Mn}(\mathrm{II})$. Fe(II) additions: ( $\square), \mathrm{Mn}(\mathrm{II})$ additions: ( $\square$ ). Metals were added at increments of 4 ions/12mer; in (A) Fe(II) was added before $\mathrm{Mn}$ (II), in (B) the order of metal addition was reversed. Protein concentration was $2 \mu \mathrm{M}$. The insets show the fluorescence spectra recorded at $298 \mathrm{~K}$. The data points are averages of three to five measurements using 2 independent protein preparations. The standard deviation was $\leq 5 \%$.

of the ferroxidase center, in accordance with the X-ray crystal structure, while $\mathrm{Fe}(\mathrm{II})$ can bind also to the low affinity B site. It appears therefore that in $\mathrm{KrDps}$ a hetero-metallic ferroxidase center is formed by adding $12 \mathrm{Mn}$ (II) prior to $12 \mathrm{Fe}$ (II).

To prove this contention, anaerobic EPR titrations with Fe(II) and $\mathrm{Mn}$ (II) were performed. The spectra were measured after addition of $\mathrm{Mn}$ (II) to $35 \mu \mathrm{M} \mathrm{KrDps}$ at molar ratios of 8 and $12 \mathrm{Mn}$ (II)/12mer. They point to binding of the metal to $\mathrm{KrDps}$ with low symmetry (Figs. 5, 6A and B, spectrum 1). The spectra are characterized by many bands contributing to the signal over a wide field range as in the case of $\mathrm{Mn}$ (II) bound to S. solfataricus Dps [37]. In another set of titrations, $\mathrm{Fe}(\mathrm{II})$ and $\mathrm{Mn}(\mathrm{II})$, both at molar ratios of 12 ions/12mer, were added to $\mathrm{KrDps}$ in sequence. Irrespective of the order of addition of the two metals, the spectra (Fig. 6A, spectra 2 and 3 ) are quite similar in the $g=4.3$ region $(B \approx 1500 \mathrm{G})$, but differ from the spectrum pertaining to $\mathrm{Mn}$ (II)-bound $\mathrm{KrDps}$ (Fig. $6 \mathrm{~A}$, spectrum 1 ). The changes are small, suggesting that $\mathrm{Mn}(\mathrm{II})$ is coordinated to the same site also in the presence of iron. The EPR spectrum of $\mathrm{KrDps}$ loaded with 12 $\mathrm{Fe}(\mathrm{II})$ and oxidized by $\mathrm{H}_{2} \mathrm{O}_{2}$ is reported in Fig. 6, spectrum 5. This spectrum (Fig. $6 \mathrm{~B}$ ) consists mainly of two signals: one at $\mathrm{g} \approx 2$ $(B \approx 3350 \mathrm{G})$ due to a radical species and a second one at $\mathrm{g}=4.3$ $(B \approx 1500 \mathrm{G})$ typical for mononuclear high-spin $(S=5 / 2) \mathrm{Fe}(\mathrm{III})$ in sites of low symmetry (Fig. $6 \mathrm{~A}$ ). This $\mathrm{g}=4.3$ signal is present also in the spectra measured when the protein is incubated with 12 $\mathrm{Mn}+12 \mathrm{Fe} / 12 \mathrm{mer}$, independently from the order of metal addition (Fig. 6A, spectra 2 and 3). Importantly, when both metals are bound, the width of the $g=4.3$ signal increases by approximately $10 \mathrm{G}$ relative to the spectrum measured with $\mathrm{Fe}(\mathrm{III})$ bound to the ferroxidase center (Fig. 6A) indicating a possible dipolar interaction between $\mathrm{Mn}$ (II) and $\mathrm{Fe}(\mathrm{III})$. When $\mathrm{Mn}(\mathrm{II})$ is bound to $\mathrm{KrDps}$, part of

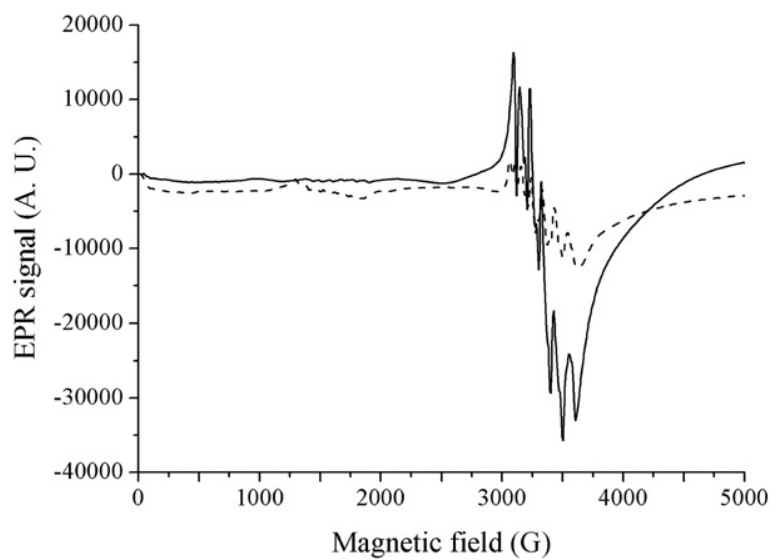

Fig. 5. Perpendicular-mode EPR spectra of $K$. radiotolerans Dps with $8 \mathrm{Mn}(\mathrm{II}) / 12 \mathrm{mer}$ Protein concentration, $35 \mu \mathrm{M}$. Acquisition temperature, $30 \mathrm{~K}$. Mn(II)-bound protein (dashed line) and $\mathrm{Mn}$ (II) in buffer at equivalent concentration (solid line).

$\mathrm{Fe}(\mathrm{II})$ is oxidized prior to the addition of $\mathrm{H}_{2} \mathrm{O}_{2}$, likely due to a small $\mathrm{O}_{2}$ leakage (see below).

The EPR data also point to differences in the development of intra-protein radicals related to the presence of the Mn-Fe center. Thus, when $12 \mathrm{Fe}(\mathrm{II})$ are oxidized at the ferroxidase center by $\mathrm{H}_{2} \mathrm{O}_{2}$,
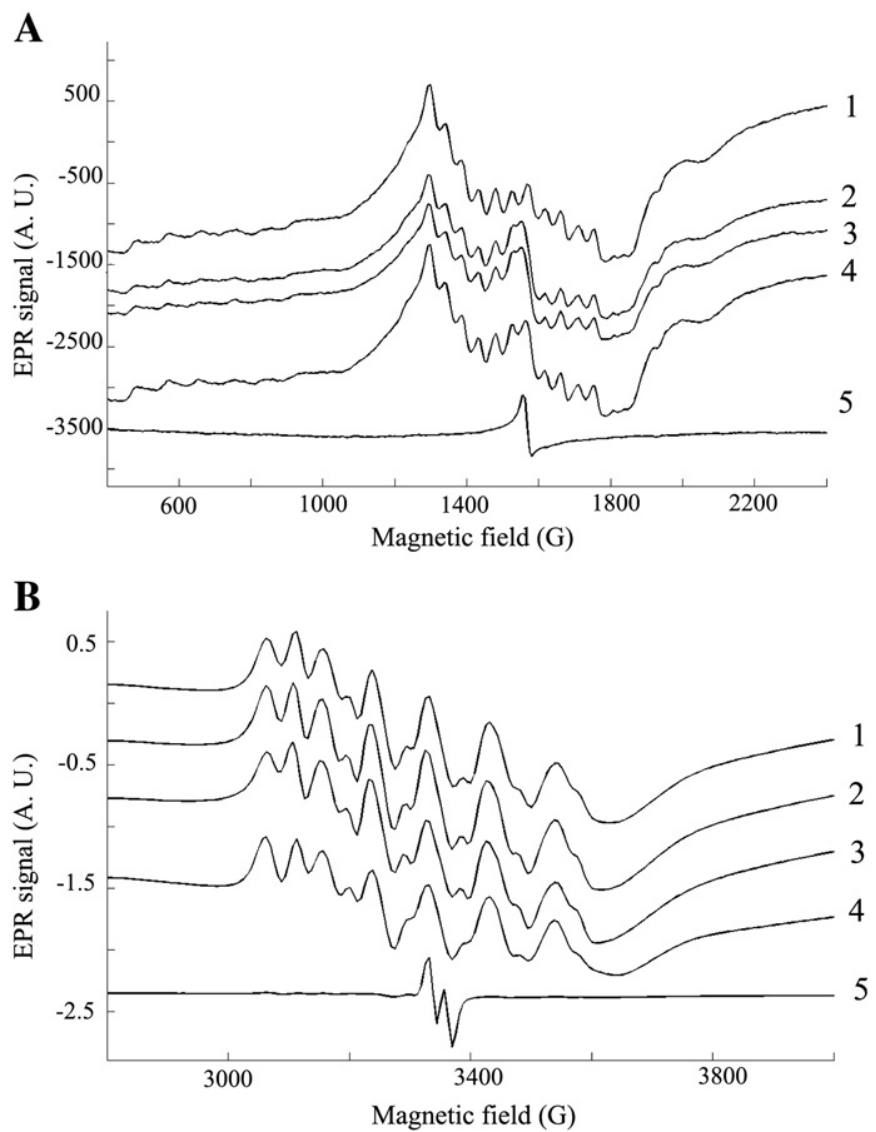

Fig. 6. Perpendicular-mode EPR spectra of $K$. radiotolerans Dps with $\mathrm{Mn}(\mathrm{II})$ and $\mathrm{Fe}(\mathrm{II})$ at molar ratios of 12 metal ions/12mer. Protein concentration, $35 \mu \mathrm{M}$. Acquisition temperature, $30 \mathrm{~K}$. In A: Blow-up of the $\mathrm{g}=4.3$ region. KrDps with $\mathrm{Mn}$ (II) in anaerobiosis (spectrum 1); with $\mathrm{Mn}(\mathrm{II})$ and $\mathrm{Fe}(\mathrm{II})$ added after $\mathrm{Mn}$ (II) in anaerobiosis (spectrum 2); with $\mathrm{Fe}(\mathrm{II})$ and $\mathrm{Mn}$ (II) added after $\mathrm{Fe}(\mathrm{II})$ in anaerobiosis (spectrum 3); with $\mathrm{Fe}(\mathrm{II}), \mathrm{Mn}$ (II) and $\mathrm{H}_{2} \mathrm{O}_{2}$ (spectrum 4); with $\mathrm{Fe}$ (II) and $\mathrm{H}_{2} \mathrm{O}_{2}$ (spectrum 5). In B: Blow-up of the $\mathrm{g}=2.0$ region. $\mathrm{KrDps}$ with $\mathrm{Mn}(\mathrm{II})$ in anaerobiosis (spectrum 1 ); with $\mathrm{Mn}(\mathrm{II})$ and $\mathrm{Fe}(\mathrm{II}$ ) added after $\mathrm{Mn}$ (II) in anaerobiosis (spectrum 2); with $\mathrm{Fe}$ (II) and $\mathrm{Mn}$ (II) added after $\mathrm{Fe}$ (II) in anaerobiosis (spectrum 3); with $\mathrm{Fe}(\mathrm{II}), \mathrm{Mn}$ (II) and $\mathrm{H}_{2} \mathrm{O}_{2}$ (spectrum 4); with $\mathrm{Fe}$ (II) and $\mathrm{H}_{2} \mathrm{O}_{2}$ (spectrum 5). 
a radical species at $g=2.0$ is formed (Fig. $6 \mathrm{~B}$, spectrum 5 ). When $\mathrm{Mn}(\mathrm{II})$ is bound to the ferroxidase center, the signal attributed to the radical points to an effect of $\mathrm{Mn}$ (II) on the reaction mechanism (Fig. 6B, spectra 1-4).

The $\mathrm{KrDps}$ capacity to incorporate $\mathrm{Fe}(\mathrm{II})$ or $\mathrm{Mn}$ (II) inside the protein shell was assayed by sedimentation velocity after a $2 \mathrm{~h}$ incubation of the protein as purified in the presence of $\mathrm{O}_{2}$ or $\mathrm{H}_{2} \mathrm{O}_{2}$ as iron oxidant. The metal ion/12mer ratio was 240 , i.e. half the typical Dps iron storage capacity [24]. As expected, $\mathrm{KrDps}$ incorporates Fe in the presence of $\mathrm{H}_{2} \mathrm{O}_{2}$ ( $\left.\mathrm{s}_{20, \mathrm{w}} 14 \mathrm{~S}\right)$. $\mathrm{Mn}$ (II) incorporation does not take place irrespective of the oxidant since the $s_{20, w}$ value is unchanged $(\sim 10 \mathrm{~S})$ relative to $\mathrm{KrDps}$ as purified (data not shown).

\subsection{Redox activity of $\mathrm{Fe}(\mathrm{II})$ and $\mathrm{Mn}(\mathrm{II})$ in the presence of molecular oxygen}

$\mathrm{Fe}$ (II) added to $\mathrm{KrDps}$ at 12,24 and 48/12mer in the presence of $\mathrm{O}_{2}$ is oxidized slowly to ferric oxy-hydroxide as in all Dps proteins [10]. The time course of $\mathrm{Fe}(\mathrm{II})$ oxidation by $\mathrm{KrDps}$, monitored by the absorbance increase at $310 \mathrm{~nm}$, is hyperbolic at 12 and $24 \mathrm{Fe} / 12 \mathrm{mer}$ and becomes sigmoidal at $48 \mathrm{Fe} / 12 \mathrm{mer}$, as expected due to the onset of the ferric hydroxide nucleation reaction. Interestingly, the initial rates (determined by a linear fit of the data points from 0 to $100 \mathrm{~s}$ after $\mathrm{Fe}(\mathrm{II})$ addition) and the amounts of $\mathrm{Fe}(\mathrm{III})$ do not depend linearly on metal concentration. The absorbance value attained 60 min after addition of 12,24 and $48 \mathrm{Fe}(\mathrm{II}) / 12$ mer corresponds to $42 \pm 1,66 \pm 3$ and $86 \pm 1 \%$ oxidized iron (Fig. 7A). The initial iron oxidation rate when $\mathrm{KrDps}$ contains $12 \mathrm{Fe}(\mathrm{II}) / 12 \mathrm{mer}$ is extremely slow $\left(4.6 \times 10^{-8} \mathrm{M} \mathrm{s}^{-1}\right)$, much slower than the Fe(II) auto-oxidation rate (not shown), and increases to $25 \times 10^{-8} \mathrm{M} \mathrm{s}^{-1}$ and $110 \times 10^{-8} \mathrm{M} \mathrm{s}^{-1}$ respectively for $\mathrm{KrDps}$ with 24 and $48 \mathrm{Fe}(\mathrm{II}) / 12$ mer.

The possible redox activity of $\mathrm{Mn}$ (II) was assayed by adding Fe(II) to KrDps pre-loaded with an equal amount of $\mathrm{Mn}(\mathrm{II})$, since Mn oxidation cannot be monitored directly by UV/visible absorbance spectroscopy. The absorbance at $310 \mathrm{~nm}$ was recorded after adding successively $\mathrm{Mn}(\mathrm{II})$ and $\mathrm{Fe}(\mathrm{II})$ to $\mathrm{KrDps}$, each at 12 ions/12mer. The data, included in Fig. 7A, show that the initial ferroxidation rate of $\mathrm{KrDps}$ with 12 $\mathrm{Mn}(\mathrm{II})+12 \mathrm{Fe}(\mathrm{II}) / 12$ mer corresponds to $9 \times 10^{-8} \mathrm{M} \mathrm{s}^{-1}$, a value intermediate between those of the protein with 12 and $24 \mathrm{Fe}(\mathrm{II}) / 12 \mathrm{mer}$, indicating that A site-bound $\mathrm{Mn}(\mathrm{II})$ participates in redox cycling. Similarly, upon addition of $24 \mathrm{Mn}$ (II) followed by $24 \mathrm{Fe}(\mathrm{II}) / 12 \mathrm{mer}$, the initial iron oxidation rate in air is intermediate $\left(39 \times 10^{-8} \mathrm{M} \mathrm{s}^{-1}\right)$ between those observed after addition of 24 and $48 \mathrm{Fe}(\mathrm{II}) / 12 \mathrm{mer}$. The amount of iron oxidized after $60 \mathrm{~min}$ is significantly higher when $\mathrm{Mn}(\mathrm{II})$ is present ( $94 \pm 3 \%$ ) relative to $\mathrm{KrDps}$ with just $24 \mathrm{Fe}(\mathrm{II}) / 12 \mathrm{mer}$ (66 $\pm 3 \%$ ). The presence of $\mathrm{Mn}$ (II) appears to be less effective when both ions are at molar ratios of $48 / 12 \mathrm{mer}$, due to the above-mentioned contribution of the ferric hydroxide nucleation reaction.

The participation of $\mathrm{Mn}(\mathrm{II})$ in redox cycling is supported by experiments in which the order of metal addition was reversed. Fig. 7B shows the data obtained when both $\mathrm{Mn}(\mathrm{II})$ and $\mathrm{Fe}(\mathrm{II})$ are at 12 ions/ 12 mer. When $\mathrm{Fe}(\mathrm{II})$ is added before $\mathrm{Mn}(\mathrm{II})$, the rate of iron oxidation $\left(5.5 \times 10^{-8} \mathrm{M} \mathrm{s}^{-1}\right)$ is intermediate between those observed when $\mathrm{Mn}$ (II) is added prior to $\mathrm{Fe}$ (II) $\left(9.0 \times 10^{-8} \mathrm{M} \mathrm{s}^{-1}\right)$ and that observed in the presence of $12 \mathrm{Fe}$ (II) only $\left(4.6 \times 10^{-8} \mathrm{M} \mathrm{s}^{-1}\right)$. KrDps(W56F) behaves like the wt protein (data not shown). In control experiments, the rate of Fe auto-oxidation was shown to be not affected by the presence of $\mathrm{Mn}$ (II) at all concentrations used (not shown).

A last set of experiments was carried out to confirm the ability of $\mathrm{Fe}$ (II) in excess to displace $\mathrm{Mn}$ (II) from the A site as indicated by the fluorescence data and by the effect of $\mathrm{Mn}$ (II) on the ferroxidation reaction just described. Given that the affinity of $\mathrm{Mn}$ (II) for the A site is only marginally higher than that of $\mathrm{Fe}(\mathrm{II})$ - the estimated respective $\mathrm{K}_{\mathrm{D}}$ values are $\sim 8 \mu \mathrm{M}$ and $6.5 \mu \mathrm{M}$ - even a relatively small molar excess of $\mathrm{Fe}(\mathrm{II})$ is expected to decrease the occupancy of the A site by $\mathrm{Mn}(\mathrm{II})$. On this basis, when $12 \mathrm{Fe}(\mathrm{II}) / 12$ mer are added in succession to the
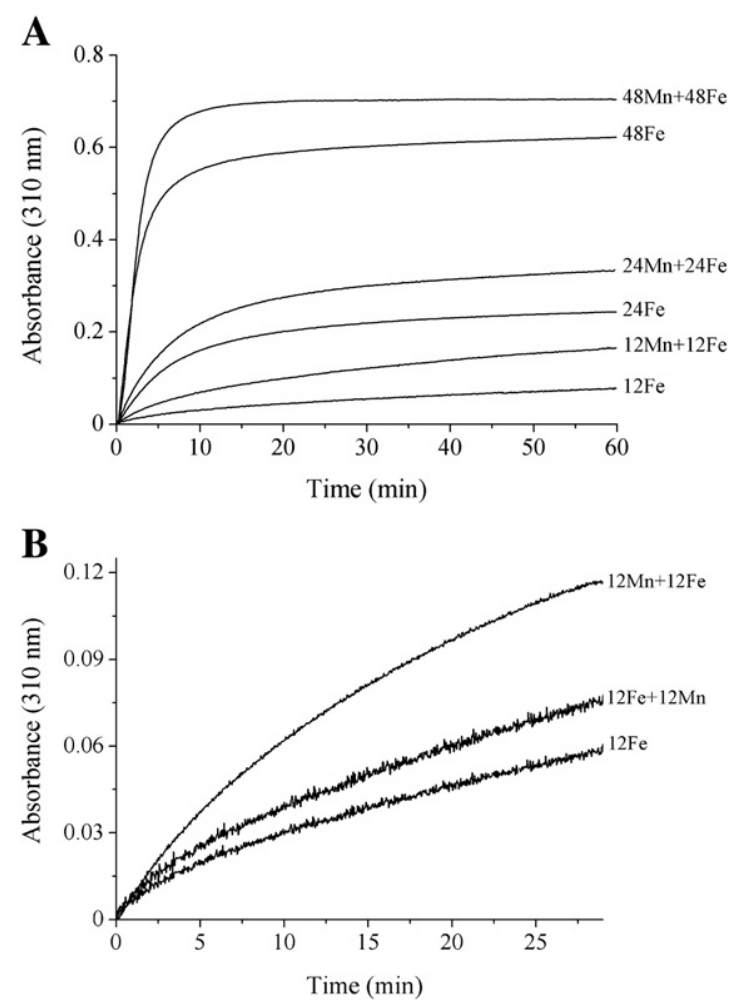

Fig. 7. Effect of $\mathrm{Mn}(\mathrm{II})$ on the kinetics of $\mathrm{Fe}(\mathrm{II})$ oxidation by $\mathrm{O}_{2}$ in the presence of $\mathrm{KrDps}$ at the indicated metal ions to protein ratios. A) Protein concentration was $6 \mu \mathrm{M}$, temperature, $298 \mathrm{~K}$. The end points of the absorbance values recorded at $310 \mathrm{~nm}$, using the

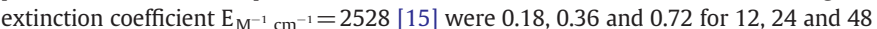
$\mathrm{Fe}(\mathrm{II}) / 12 \mathrm{mer}$, respectively. B) Protein concentration was $4.6 \mu \mathrm{M}$; the end point of the absorbance value at $310 \mathrm{~nm}$ was 0.14

same sample loaded with $\mathrm{Mn}(\mathrm{II})$, the effect of the latter metal ion on the ferroxidation reaction is expected to decrease progressively upon increase in $\mathrm{Fe}$ (II) concentration and eventually vanish when the amount of $\mathrm{Fe}$ (II) suffices to displace all the A site bound $\mathrm{Mn}$ (II). In fact, the rates observed upon three subsequent additions of $12 \mathrm{Fe} /$ 12 mer to $6.5 \mu \mathrm{M} \mathrm{KrDps}$ containing $12 \mathrm{Mn} / 12$ mer are 11.4, 22.2 and $20.4 \times 10^{-8} \mathrm{M} \mathrm{s}^{-1}$ whereas the values obtained in parallel on $\mathrm{KrDps}$ that does not contain $\mathrm{Mn}(\mathrm{II})$ are $5.2,9.5$, and $18.8 \times 10^{-8} \mathrm{M} \mathrm{s}^{-1}$.

Taken together these data indicate that A site-bound Mn participates in redox cycling only when $\mathrm{Fe}(\mathrm{II})$ is bound to the $\mathrm{KrDps}$ ferroxidase center B site, an assertion confirmed by the oxygraphic experiments carried out on L. innocua Dps (see below).

The catalytic role of $\mathrm{Mn}(\mathrm{II})$ in the ferroxidation reaction by $\mathrm{O}_{2}$ emerges clearly from Table 2, where the available data on Fe(II) binding affinities at the ferroxidase center A site and on the ferroxidation rates by $\mathrm{O}_{2}$ of known Dps proteins are compiled.

\subsection{Effect of $\mathrm{Mn}$ (II) on the $\mathrm{Fe}(\mathrm{II})$ oxidation reaction by hydrogen peroxide}

To establish whether Mn affects the production of short-lived intra-protein radical species that trap $\mathrm{OH}^{*}$ during $\mathrm{Fe}(\mathrm{II})$ oxidation by $\mathrm{H}_{2} \mathrm{O}_{2}$, rapid mixing experiments were performed. Formation of intra-protein radical species implies that a mono electron transfer process is operative and involves aromatic residues in the neighborhood of the ferroxidase center as in LiDps and EcDps [38].

The ferroxidation reaction was followed between 350 and $700 \mathrm{~nm}$ by measuring the absorbance changes that occur $300 \mathrm{~ms}$ after the sequential mixing of $6 \mathrm{Fe}$ and $3 \mathrm{H}_{2} \mathrm{O}_{2}$ with $\sim 17 \mu \mathrm{M} \mathrm{KrDps}$. A broad band centered around $524 \mathrm{~nm}$ with two maxima at $\sim 512$ and $550 \mathrm{~nm}$ is formed $2.5 \mathrm{~ms}$ after mixing (Fig. 8A) as in the case of LiDps and EcDps under the same experimental conditions [38]. In EcDps these 
Table 2

$\mathrm{Fe}$ (II) affinity for the ferroxidase center A site of Dps proteins and rate of oxidation by $\mathrm{O}_{2}$. The apparent affinity constant for $\mathrm{Fe}(\mathrm{II})$ binding to the indicated Dps proteins was assessed by means of anaerobic fluorescence titrations $\left({ }^{*}\right)$ or ITC $\left({ }^{\circ}\right)$; the rates of Fe(II) oxidation were obtained at protein concentrations of $\sim 6 \mu \mathrm{M}$ and $25{ }^{\circ} \mathrm{C}$.

\begin{tabular}{llllll}
\hline Protein & $\begin{array}{l}\mathrm{K}_{\mathrm{A}}(\text { site } \mathrm{A}) \\
\left(\mathrm{M}^{-1}\right)\end{array}$ & \multicolumn{2}{l}{$\mathrm{Fe}(\mathrm{II})$ oxidation } & pH & Ref. \\
\cline { 3 - 4 } & & Metal/12mer & Rate $\left(\mathrm{M} \times \mathrm{s}^{-1}\right)$ & & \\
\hline \multirow{2}{*}{ KrDps } & $>1.5 \times 10^{5^{*}}$ & $12 \mathrm{Fe}(\mathrm{II})$ & $4.6 \times 10^{-8}$ & 7.4 & This work \\
& - & $24 \mathrm{Fe}(\mathrm{II})$ & $25.0 \times 10^{-8}$ & 7.4 & This work \\
& - & $48 \mathrm{Fe}(\mathrm{II})$ & $110.0 \times 10^{-8}$ & 7.4 & This work \\
& & $12 \mathrm{Mn}(\mathrm{II})+12 \mathrm{Fe}(\mathrm{II})$ & $9.0 \times 10^{-8}$ & 7.4 & This work \\
LiDps & $>1.3 \times 10^{5^{*}}$ & $12 \mathrm{Fe}(\mathrm{II})$ & - & 7.0 & Ref. [36] \\
& $4.4 \times 10^{70}$ & $24 \mathrm{Fe}(\mathrm{II})$ & $7.2 \times 10^{-8}$ & 7.0 & Ref. [36] \\
& $>1.2 \times 10^{5^{*}}$ & $12 \mathrm{Fe}(\mathrm{II})$ & $4.8 \times 10^{-8}$ & 7.4 & This work \\
& - & $24 \mathrm{Fe}(\mathrm{II})$ & $24.0 \times 10^{-8}$ & 7.4 & This work \\
& - & $48 \mathrm{Fe}(\mathrm{II})$ & $105.0 \times 10^{-8}$ & 7.4 & This work \\
& & $12 \mathrm{Mn}(\mathrm{II})+12 \mathrm{Fe}(\mathrm{II})$ & $9.2 \times 10^{-8}$ & 7.4 & This work \\
EcDps & - & $24 \mathrm{Fe}(\mathrm{II})$ & $18.0 \times 10^{-8}$ & 7.0 & Ref. [41] \\
TeDps & - & $24 \mathrm{Fe}(\mathrm{II})$ & $13.6 \times 10^{-8}$ & 7.0 & Ref. [31] \\
\hline
\end{tabular}

bands have been attributed to intra-protein radicals formed by Trp52. In LiDps a broad band with a maximum between 550 and $600 \mathrm{~nm}$ is also formed. It has been assigned to Trp32 in radical (Trp ${ }^{*}$ ) and in cation radical form $\left(\operatorname{Trp}^{\bullet+}\right)$, respectively [38]. In $\mathrm{KrDps}$, the broad band

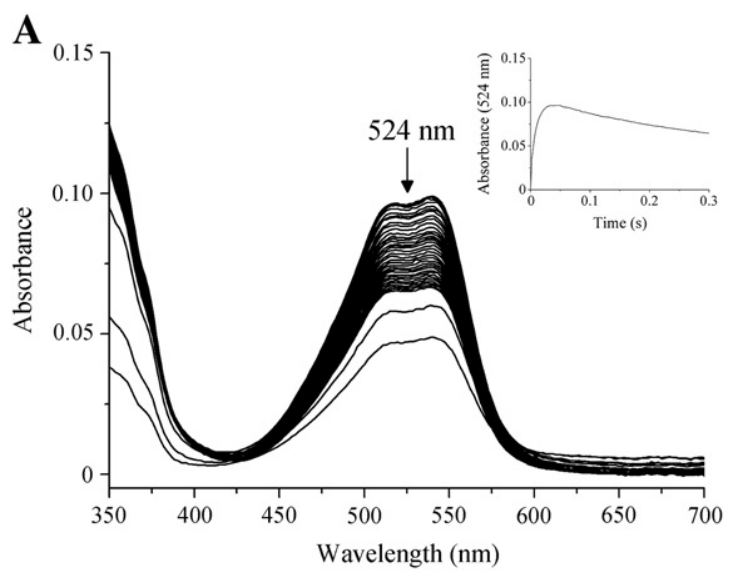

$\mathbf{B}$

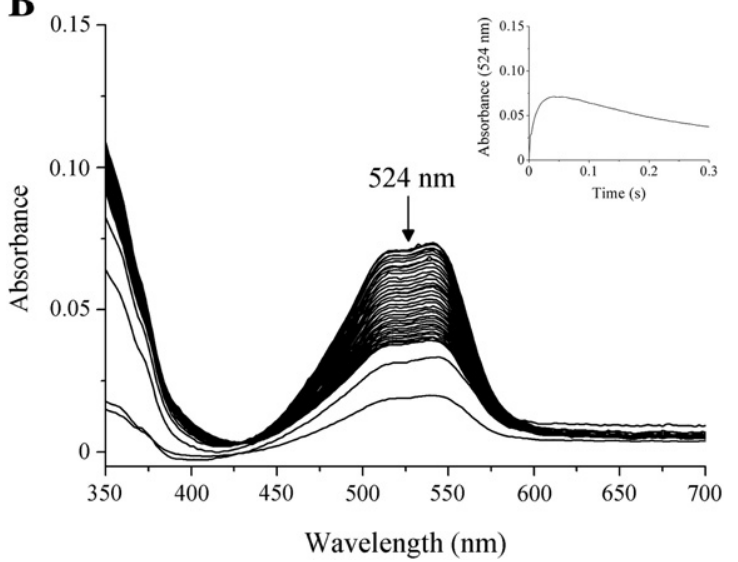

Fig. 8. Effect of $\mathrm{Mn}(\mathrm{II})$ on the $\mathrm{Fe}$ (II) oxidation reaction by $\mathrm{H}_{2} \mathrm{O}_{2}$. Spectral changes occurring in a $\mathrm{KrDps}$ solution during the first $300 \mathrm{~ms}$ of the oxidation reaction followed in a stopped-flow apparatus in the sequential mixing mode. In (A) KrDps was mixed with 6 $\mathrm{Fe}(\mathrm{II}) / 12 \mathrm{mer}$ and thereafter with $3 \mathrm{H}_{2} \mathrm{O}_{2} / 12 \mathrm{mer}$; in (B) KrDps pre-loaded with 12 $\mathrm{Mn}(\mathrm{II}) / 12$ mer was mixed with $6 \mathrm{Fe}(\mathrm{II}) / 12$ mer and thereafter with $3 \mathrm{H}_{2} \mathrm{O}_{2} / 12$ mer. Concentrations after mixing: $17 \mu \mathrm{M}$ protein, $100 \mu \mathrm{M} \mathrm{FeSO}_{4}, 200 \mu \mathrm{M} \mathrm{MnCl}_{2}$ and $50 \mu \mathrm{M} \mathrm{H}_{2} \mathrm{O}_{2}$ in $50 \mathrm{mM}$ MOPS-NaOH buffer, $\mathrm{pH} 7.4$ and $200 \mathrm{mM} \mathrm{NaCl}$; temperature $=293 \mathrm{~K}$. The reported spectra are taken every $6 \mathrm{~ms}$. Insets report the time course of Trp formation assessed at $524 \mathrm{~nm}$. The $\mathrm{k}$ values for the first phase of the reaction obtained by fitting the traces to a double-exponential time course are $118 \mathrm{~s}^{-1}$ (A) and $99 \mathrm{~s}^{-1}$ (B) centered at $524 \mathrm{~nm}$ can be ascribed to the corresponding Trp49. The Trp $49^{\circ}$ yield is $\approx 20 \%$ based on the published extinction coefficient [21], a somewhat lower value relative to LiDps and EcDps [38]. The KrDps transient spectra do not show the $410 \mathrm{~nm}$ band attributed to a Tyr50 radical in LiDps in accordance with the presence of Val67 in the corresponding position (Fig. 1, panel B). Similarly, the $410 \mathrm{~nm}$ band is not formed in EcDps where Tyr50 is substituted with Arg.

In KrDps preloaded with $12 \mathrm{Mn}$ (II)/12mer, the broad band attributed to Trp $49^{\circ}$ formed upon addition of $6 \mathrm{Fe}(\mathrm{II})+3 \mathrm{H}_{2} \mathrm{O}_{2} / 12$ mer has a lower intensity, corresponding to $\mathrm{a} \approx 14 \%$ yield (Fig. $8 \mathrm{~B}$ ) in line with the effect of $\mathrm{Mn}$ (II) on the reaction mechanism indicated by the EPR spectra depicted in Fig. 6B. No absorbance bands are detected when $12 \mathrm{Mn}(\mathrm{II})+3 \mathrm{H}_{2} \mathrm{O}_{2} / 12$ mer are added to $\mathrm{KrDps}$ (data not shown) an indication that no intra-protein $\operatorname{Trp}^{\circ}$ is produced unless iron is bound at the ferroxidase center.

\section{6. $\mathrm{Mn}$ (II) and Fe(II) binding to L. innocua Dps as a model system}

To establish the generality of the $\mathrm{Mn}(\mathrm{II})$ binding and oxidation capacity of the Dps ferroxidase center, the well characterized LiDps was used under the same conditions employed for $K r D p s$ albeit without $\mathrm{NaCl}$ in the buffer. The two Dps proteins behave very similarly as shown in Fig. S3, panels A-E. Oxygraphic assays were also performed to detect $\mathrm{O}_{2}$ consumption upon addition of $\mathrm{Fe}(\mathrm{II})$ to $\mathrm{LiDps}$ in the presence and absence of $\mathrm{Mn}(\mathrm{II})$. Importantly, no $\mathrm{O}_{2}$ is consumed when $\mathrm{Mn}$ (II) is added to the buffer in the absence of protein. In contrast, $\mathrm{O}_{2}$ consumption takes place at $95 \mathrm{nmol}^{-1}$ when $\mathrm{Fe}(\mathrm{II})$ is present (Fig. S4). In accordance with the spectrophotometric assays, $\mathrm{O}_{2}$ consumption is accelerated when $\mathrm{KrDps}$ contains both $\mathrm{Mn}$ and Fe.

\section{Discussion}

$\mathrm{Mn}$ (II) binding at the ferroxidase center of Dps proteins and its participation in redox cycling during $\mathrm{Fe}(\mathrm{II})$ oxidation are of interest from different perspectives. In radiation-resistant bacteria, whose cytoplasm is especially rich in $\mathrm{Mn}$ (II) and poor in $\mathrm{Fe}(\mathrm{II})$, it provides a likely molecular mechanism for the protective role exerted by Mn under oxidative stress conditions. From a general viewpoint it brings out that the Dps ferroxidase center can operate also in a transient hetero-bimetallic state, with $\mathrm{Mn}(\mathrm{II})$ at the $\mathrm{A}$ site and $\mathrm{Fe}(\mathrm{II})$ at the $\mathrm{B}$ one, a condition where functional differences between the two sites are manifested. The metal bound to the high affinity A site, be it $\mathrm{Fe}(\mathrm{II})$ or $\mathrm{Mn}(\mathrm{II})$, appears to play a catalytic role during ferroxidation, whereas the B site-bound $\mathrm{Fe}(\mathrm{II})$ acts as a substrate that leaves the site after oxidation and can be substituted by incoming Fe(II). Importantly, A site-bound $\mathrm{Mn}(\mathrm{II})$ does not undergo redox processes unless the B site contains $\mathrm{Fe}(\mathrm{II})$.

The crystallographic structure of Mn(II)-containing $\mathrm{KrDps}$ clearly reveals that $\mathrm{Mn}$ (II) binds at the high affinity A site, whereas the B site remains metal-free (Fig. 3A), even though the metal added (24 Mn(II)/ $12 \mathrm{mer}$ ) suffices to saturate both sites at the concentrations used for crystallization. The structural reason for the higher affinity of $\mathrm{Mn}$ (II) for the A site relative to iron is not known. The A site-bound $\mathrm{Mn}$ (II) is hexa-coordinated: Asp75, Glu79 and His48 correspond to the canonical $\mathrm{Fe}(\mathrm{II})$ binding residues and furnish four ligands, while the other two ligands are provided by water molecules. One $\mathrm{H}_{2} \mathrm{O}$ is anchored in position by Lys45 and Asp64. A comparison with $\mathrm{Mn}$ (II) binding at the structurally related ferroxidase centers is in order. In the ferroxidase center of S. suis Dpr, differences in the $\mathrm{Mn}$ (II) ligands relative to $\mathrm{KrDps}$ are apparent. In particular, His59 (corresponding to His60, a B site metal ligand in $\mathrm{KrDps}$ ) does not contribute to metal binding due to the lack of the water molecule (W2011-C) that bridges $\mathrm{Mn}$ (II) and His60 in KrDps. Moreover, Glu78 is unable to provide a mono-dentate $\mathrm{Mn}$ (II) ligand at the B site as it is slightly tilted away from the ferroxidase center, whereas the corresponding Glu79 is a bi-dentate ligand in the structures of $\mathrm{Mn}$ (II)-bound $\mathrm{KrDps}$. The binuclear ferroxidase 
center of the dodecameric Dps-like protein from S. solfataricus, is buried within the four-helix bundle of each monomer as in bacterioferritins and mammalian ferritins, and is able to bind both iron and manganese. Each metal is coordinated by Glu, His, and one water molecule, with the two metals bridged by a glutamic acid carboxylate [14]. A heteronuclear Mn-Fe cofactor has been described also in the so-called class I ribonucleotide reductases (RNRs), like C. trachomatis RNR [13], where it takes the place of the typical Fe-Fe cofactor. The overall configuration of the Mn-Fe center and of the homo-metallic iron one in conventional RNRs is alike, an observation that accounts for the binding of two $\mathrm{Mn}$ (II) in E. coli RNR (PDB ID: 3N37). In this protein, bound $\mathrm{Mn}$ (II) is hexacoordinated: one $\mathrm{Mn}(\mathrm{II})$ ion is ligated by His, a water molecule and three Glu residues (one provides a bi-dentate interaction), while the other $\mathrm{Mn}(\mathrm{II})$ is coordinated by His, Asp, three Glu residues and a water molecule [39].

KrDps possesses other $\mathrm{Mn}(\mathrm{II})$ binding sites at the "ferritin-like" and "Dps-type" interfaces (Fig. S1, panels B and C). Metal binding at the latter position has not been observed in other Dps proteins likely due to the variability of the residues lining this interface. In fact, the $\mathrm{KrDps} \mathrm{Mn}(\mathrm{II})$ binding residues Asn55 and Asp58 are conserved in MsDps2 [22], but not in LiDps [23], EcDps [29] and SsDpr [35]. In turn, $\mathrm{Mn}(\mathrm{II})$ bound at the KrDps "Dps-type" pore entrance suggests that $K r D p s$ may use these pores for metal passage towards the ferroxidase center. Furthermore, $\mathrm{KrDps}$ contains an unusual Trp residue (Trp56) which substitutes the otherwise conserved Phe and is located at less than $4 \AA$ from the ferroxidase center B site and at $9 \AA$ from Mn bound at the "Dps-type" interface. However, given the similar behavior of the wt protein and of the $\operatorname{KrDps}(\mathrm{W} 56 \mathrm{~F})$ mutant, Trp56 is unlikely to play a significant role in metal binding.

In full agreement with the crystallographic data, which show that $\mathrm{Mn}(\mathrm{II})$ binding at the ferroxidase center involves only the A sites, the anaerobic fluorescence titrations indicate binding of $12 \mathrm{Mn}(\mathrm{II}) / 12 \mathrm{mer}$ with high affinity, in contrast with the binding of $24 \mathrm{Fe}(\mathrm{II}) / 12 \mathrm{mer}$ at both the A and B sites (Fig. 4A and B). In turn, when Mn(II) and $\mathrm{Fe}(\mathrm{II})$ are added to $\mathrm{KrDps}$ in succession at 12 ions/12mer, this characteristic can lead to formation of a hetero-nuclear ferroxidase center with $\mathrm{Mn}$ (II) bound at the A site and $\mathrm{Fe}(\mathrm{II})$ at the $\mathrm{B}$ site. $\mathrm{Mn}$ (II) and $\mathrm{Fe}$ (II) bind to the A site with similar affinities such that $\mathrm{Mn}$ (II) is displaced by $\mathrm{Fe}(\mathrm{II})$ in molar excess as indicated by the observed ferroxidation rates when successive amounts of $\mathrm{Fe}(\mathrm{II})$ are added to $\mathrm{KrDps}$ in the presence or absence of $\mathrm{Mn}(\mathrm{II})$ at the ferroxidase A site and by the fluorescence titrations (Fig. 4).

In the ferroxidation reaction, the Mn-Fe hetero-nuclear center behaves differently from the canonical $\mathrm{Fe}-\mathrm{Fe}$ one as the presence of $\mathrm{Mn}$ (II) renders $\mathrm{Fe}(\mathrm{II})$ oxidation by $\mathrm{O}_{2}$ more effective (Fig. 7A, B). This situation recalls the higher efficiency of the $C$. trachomatis RNR MnFe cluster relative to the typical Fe-Fe cofactor in providing the oxidation equivalent needed to initiate catalysis [13]. In Mn-Fe-KrDps, oxidation of B-site bound $\mathrm{Fe}(\mathrm{II})$ is faster than in the Fe-Fe containing protein and is complete after $60 \mathrm{~min}$ in air. This finding clearly indicates that $\mathrm{Mn}$ (II) undergoes redox cycling and favors Fe(II) oxidation at the $\mathrm{B}$ site. In the absence of $\mathrm{Mn}(\mathrm{II}), \mathrm{Fe}(\mathrm{II})$ oxidation by $\mathrm{O}_{2}$ is not complete under the same conditions and, intriguingly, the amount of $\mathrm{Fe}(\mathrm{III})$ formed does not correspond to the total amount of $\mathrm{Fe}(\mathrm{II})$, but rather to that of $\mathrm{B}$ site-bound $\mathrm{Fe}(\mathrm{II})$. It appears therefore that $\mathrm{A}$ site-bound $\mathrm{Fe}(\mathrm{II})$ and $\mathrm{Mn}(\mathrm{II})$ behave alike in that they favor $\mathrm{Fe}(\mathrm{II})$ oxidation at the $\mathrm{B}$ site.

EPR experiments prove $\mathrm{Mn}(\mathrm{II})$ binding to the $\mathrm{Kr}$ Dps ferroxidase center. Moreover, they indicate formation of a hetero-metallic cofactor when $\mathrm{Mn}$ and Fe are added sequentially in equal amounts to the protein sample and are oxidized by $\mathrm{H}_{2} \mathrm{O}_{2}$. Thus, when iron is added to $\mathrm{KrDps}$ pre-loaded with $\mathrm{Mn}(\mathrm{II})$, there is an approximately $10 \mathrm{G}$ increase of the signal in the $g=4.3$ region with respect to the protein loaded with iron only (Fig. 6A). These data point to the occurrence of a dipolar interaction between the two metals. The nature of this weak interaction is in accordance with formation of a transient hetero-nuclear $\mathrm{Mn}$ (II)-
$\mathrm{Fe}(\mathrm{III})$ center wherefrom $\mathrm{Fe}(\mathrm{III})$ bound to the B site can move to the protein cavity (see below). In the protein loaded with $12 \mathrm{Mn}$ (II)/12mer and $12 \mathrm{Fe}(\mathrm{II}) / 12 \mathrm{mer}$, the fact that part of the $\mathrm{Fe}(\mathrm{II})$ is oxidized also in absence of $\mathrm{H}_{2} \mathrm{O}_{2}$ is likely due to an oxygen leak, consistent with the increase in $\mathrm{Fe}(\mathrm{II})$ oxidation rate by $\mathrm{O}_{2}$ due to bound $\mathrm{Mn}$ (II) depicted in Fig. 7.

In mechanistic terms, these findings, which apply also to LiDps (Fig. S3, panel C), suggest different roles for the A and B sites during ferroxidation by molecular oxygen. A site-bound $\mathrm{Fe}(\mathrm{II})$ or $\mathrm{Mn}$ (II) participates in redox cycling, does not leave the A site, and hence has a mere catalytic function. In contrast, the B site-bound Fe(II) behaves like a substrate that, once oxidized, can move into the protein cavity and give rise to ferric oxy-hydroxide nuclei.

Iron oxidation by $\mathrm{H}_{2} \mathrm{O}_{2}$ in the presence of Dps proteins leads to the complete two-electron reduction of $\mathrm{H}_{2} \mathrm{O}_{2}$ to water, but is known to involve transfer of single electrons and the consequent formation of transient intra-protein radical species. These act as a short-lived radical trap that dissipates free electrons and limits the release of $\mathrm{OH}^{*}$ in solution and the ensuing oxidative DNA damage. Radical formation involves the conserved Trp and Tyr residues located near the ferroxidase center [38].

The $\mathrm{Mn}(\mathrm{II})$ redox cycling activity in the ferroxidation reaction when $\mathrm{H}_{2} \mathrm{O}_{2}$ is the oxidant is envisaged to entail the following steps:

1) A site-bound $\mathrm{Mn}(\mathrm{II})$ and $\mathrm{B}$ site-bound $\mathrm{Fe}(\mathrm{II})$ provide the electron pair for the reduction of $\mathrm{H}_{2} \mathrm{O}_{2}$ to water with formation of the transient $\mathrm{Fe}(\mathrm{II})-\mathrm{Mn}(\mathrm{III})$ intermediate detected in the EPR experiments:

$\mathrm{H}_{2} \mathrm{O}_{2}+2 \mathrm{H}^{+}+\mathrm{Mn}^{+2}+\mathrm{Fe}^{+2}=2 \mathrm{H}_{2} \mathrm{O}+\mathrm{Mn}^{+3}+\mathrm{Fe}^{+3}$

2) thereafter, oxidized $\mathrm{Fe}(\mathrm{III})$ leaves the B site and gives rise to the nucleation process in the cavity, while Mn(III) undergoes a second redox reaction by acquiring an electron from the nearby Trp49 residue through a short-range electron transfer; this process regenerates $\mathrm{Mn}$ (II) and forms the Trp radical species detected in the stopped-flow experiments presented in Fig. 8:

$$
\mathrm{Mn}^{+3}+\operatorname{Trp} 49=\mathrm{Mn}^{+2}+\operatorname{Trp} 49^{\circ}
$$

3) thereafter, another $\mathrm{Fe}(\mathrm{II})$ binds to the B site, reduces $\operatorname{Trp} 49^{\circ}$ to Trp49, and leaves the site as Fe(III), giving rise to the nucleation process in the protein cavity. In this reaction mechanism, two $\mathrm{Fe}(\mathrm{II})$ are oxidized by one $\mathrm{H}_{2} \mathrm{O}_{2}$ molecule.

When $\mathrm{O}_{2}$ acts as $\mathrm{Fe}$ (II) oxidant, since $\mathrm{H}_{2} \mathrm{O}_{2}$ is an intermediate reaction [36], the $\mathrm{Mn}$ (II) redox cycling activity can be envisaged to entail the following steps:

1) A site-bound $\mathrm{Mn}(\mathrm{II})$ and $\mathrm{B}$ site-bound $\mathrm{Fe}(\mathrm{II})$ provide the electron pair for the reduction of $\mathrm{O}_{2}$ to hydrogen peroxide:

$$
\mathrm{O}_{2}+2 \mathrm{H}^{+}+\mathrm{Mn}^{+2}+\mathrm{Fe}^{+2}=\mathrm{H}_{2} \mathrm{O}_{2}+\mathrm{Mn}^{+3}+\mathrm{Fe}^{+3}
$$

2) oxidation of another $\mathrm{Fe}(\mathrm{II})$ leads to regeneration of $\mathrm{Mn}^{2+}$ :

$$
\mathrm{Mn}^{+3}+\mathrm{Fe}^{2+}=\mathrm{Mn}^{2+}+\mathrm{Fe}^{3+}
$$

3) hydrogen peroxide is reduced by the mechanism described above:

$$
2 \mathrm{Fe}^{2+}+2 \mathrm{H}^{+}+\mathrm{H}_{2} \mathrm{O}_{2}=2 \mathrm{H}_{2} \mathrm{O}+2 \mathrm{Fe}^{3+} .
$$

The data on LiDps extend these observations and indicate that A site-bound $\mathrm{Mn}$ (II) abolishes Tyr ${ }^{*}$ formation and decreases Trp ${ }^{*}$ formation (Fig. S3, panel E). In KrDps, the relevant Tyr residue (Tyr50 in LiDps) is substituted by a valine (Fig. 1, panel B) and mono-electron transfer involves only Trp49, the conserved tryptophan localized near the catalytic site (Fig. 8A). When $\mathrm{KrDps}$ contains the hetero-nuclear Mn-Fe center, the amount of $\operatorname{Trp}^{\circ}$ decreases (Fig. $8 \mathrm{~B}$ ) and is nil in $\mathrm{KrDps}$ containing 
only $\mathrm{Mn}$ (II) (data not shown), a further indication of the absence of redox processes under this condition. The oxygraphic assays carried out on LiDps (Fig. S4) require to be recalled in this connection as they provide convincing evidence that A site-bound $\mathrm{Mn}$ (II) does not undergo redox processes unless $\mathrm{Fe}(\mathrm{II})$ is at the $\mathrm{B}$ site. The EPR spectra support this contention since the $\mathrm{g}=2$ signal, characteristic of radical species formation, is not present when $\mathrm{KrDps}$ is loaded with $12 \mathrm{Mn}$ (II)/12mer (Fig. 6B). The similarity of all the Mn(II) effects in KrDps and in LiDps, the family prototype, points to their generality.

At variance with $\mathrm{Fe}, \mathrm{Mn}$ is not incorporated in the $\mathrm{KrDps}$ cavity as shown by the $s_{20, w}$ value which is unchanged, relative to apo- $K r D p s$, after incubation with $240 \mathrm{Mn}(\mathrm{II}) / 12 \mathrm{mer}$ in the presence of $\mathrm{O}_{2}$ or $\mathrm{H}_{2} \mathrm{O}_{2}$. In contrast, $\mathrm{s}_{20, w}$ increases from $\sim 10 \mathrm{~S}$ to $\sim 14 \mathrm{~S}$ in KrDps incubated with $240 \mathrm{Fe}(\mathrm{II}) / 12$ mer. It appears therefore that $\mathrm{Mn}$ (II) acts as a catalytic element in the reduction of $\mathrm{O}_{2}$ and $\mathrm{H}_{2} \mathrm{O}_{2}$ without forming a manganese oxide or a manganese-iron oxide core within the protein shell.

\section{Conclusions}

The present data disclose that in Dps proteins metals bound at the ferroxidase center A and B sites have different functional roles. The high affinity A site can bind $\mathrm{Fe}$ (II) or $\mathrm{Mn}$ (II) which act as catalysts during ferroxidation, whereas the low affinity B site binds only $\mathrm{Fe}(\mathrm{II})$ that migrates towards the protein cavity after each ferroxidation cycle and thus behaves like a substrate. In more general terms, the capacity of Dps proteins to bind $\mathrm{Mn}(\mathrm{II})$ and use it to carry out both iron oxidation and $\mathrm{H}_{2} \mathrm{O}_{2}$ consumption can be of physiological relevance in radiationresistant bacteria that can survive exposure to strong oxidants, prolonged desiccation and other DNA-damaging agents. In these bacteria, the catalytic role of $\mathrm{Mn}$ (II) bound at the Dps ferroxidase center is expected to be significant given the high cytosolic Mn concentration and the increased Dps expression under ionizing conditions.

\section{Protein Data Bank accession codes}

The $K r$ Dps coordinates have been deposited in the Protein Data Bank with the PDB ID code 4A25 and with the structure factors code r4A25sf.

\section{Acknowledgements}

We gratefully acknowledge Dr. E. Forte for the oxygraphic experiments, Prof. C. Zamparelli for the analytical ultracentrifugation experiments, Dr. Barry D. Howes for assistance during the EPR experiments and the Helmholtz-Zentrum Berlin-Electron storage ring BESSY II for providing synchrotron radiation at beamline BL 14-1 and the funding from the European Community's Seventh Framework Program (FP7/ 2007-2013) under grant agreement no. 226716.

\section{Appendix A. Supplementary data}

Supplementary data to this article can be found online at http:// dx.doi.org/10.1016/j.bbagen.2013.02.003.

\section{References}

[1] A.G. McEvan, New insights into the protective effect of manganese against oxidative stress, Mol. Microbiol. 72 (2009) 812-814, http://10.1111/j.13652958.2009.06700.

[2] F.S. Archibald, I. Fridovich, Manganese and defences against oxygen toxicity in Lactobacillus plantarum, J. Bacteriol. 145 (1981) 442-451, (http://www.ncbi. nlm.nih.gov/pmc/articles/PMC217292/).

[3] F.S. Archibald, I. Fridovich, The scavenging of superoxide radical by manganous complexes in vitro, Arch. Biochem. Biophys. 214 (1982) 452-463, http://10.1016/00039861(82)90049-2.

[4] F.S. Ezra, D.S. Lucas, R.V. Mustacich, A.F. Russell, Phosphorus-31 and carbon-13 nuclear magnetic resonance studies of anaerobic glucose metabolism and lactate transport in Staphylococcus aureus cells, Biochemistry 22 (1983) 3841-3849, http://10.1021/bi00285a020.

[5] F.S. Ezra, D.S. Lucas, A.F. Russell, ${ }^{31}$ P-NMR and ESR studies of the oxidation states of manganese in Staphylococcus aureus, Biochim. Biophys. Acta 803 (1984) 90-94, http://10.1016/0167-4889(84)90059-4.

[6] F. Fiorini, S. Stefanini, P. Valenti, E. Chiancone, D. De Biase, Transcription of the Listeria monocytogenes fri gene is growth-phase dependent and is repressed directly by Fur, the ferric uptake regulator, Gene 410 (2008) 113-121, http:// 10.1016/j.gene.2007.12.007.

[7] H. Chen, R. Wu, G. Xu, X. Fang, X. Qiu, H. Guo, B. Tian, Y. Hua, DR2539 is a nove DtxR-like regulator of $\mathrm{Mn} / \mathrm{Fe}$ ion homeostasis and antioxidant enzyme in Deinococcus radiodurans, Biochem. Biophys. Res. Commun. 396 (2010) 413-418, http://10.1016/j.bbrc.2010.04.106.

[8] A. Anjem, S. Varghese, J.A. Imlay, Manganese import is a key element of the OxyR response to hydrogen peroxide in Escherichia coli, Mol. Microbiol. 72 (2009) 844-858, http://10.1111/j.1365-2958.2009.06699.x.

[9] A. Ilari, M.C. Latella, P. Ceci, F. Ribacchi, M. Su, L. Giangiacomo, S. Stefanini, N.D. Chasteen, E. Chiancone, The unusual intersubunit ferroxidase center of Listeria innocua Dps is required for hydrogen peroxide detoxification but not for iron uptake. A study with site-specific mutants, Biochemistry 44 (2005) 5579-5587, http://10.1021/bi050005e.

[10] F. Pacello, P. Ceci, S. Ammendola, P. Pasquali, E. Chiancone, A. Battistoni, Periplasmic $\mathrm{Cu}, \mathrm{Zn}$ superoxide dismutase and cytoplasmic Dps concur in protecting Salmonella enterica serovar Typhimurium from extracellular reactive oxygen species, Biochim. Biophys. Acta 1780 (2008) 226-232, http://10.1016/j.bbagen.2007.12.001.

[11] M.J. Daly, E.K. Gaidamakova, V.Y. Matrosova, A. Vasilenko, M. Zhai, A. Venkateswaran, M. Hess, M.V. Omelchenko, H.M. Kostandarithes, K.S. Makarova, L.P. Wackett, J.K. Fredrickson, D. Ghosal, Accumulation of $\mathrm{Mn}(\mathrm{II})$ in Deinococcus radiodurans facilitates gamma-radiation resistance, Science 306 (2004) 1025-1028, http:// 10.1126/science.1103185.

[12] M.J. Daly, A new perspective on radiation resistance based on Deinococcus radiodurans, Nat. Rev. Microbiol. 7 (2009) 237-245, http://10.1038/nrmicro2073.

[13] N. Voevodskaya, F. Lendzian, O. Sanganas, A. Grundmeier, A. Gräslund, M. Haumann, Redox intermediates of the Mn-Fe site in subunit R2 of Chlamydia trachomatis ribonucleotide reductase. An X-ray absorption and EPR study, J. Biol. Chem. 284 (2009) 4555-4566, http://10.1074/jbc.M807190200.

[14] G.H. Gauss, P. Benas, B. Wiedenheft, M. Young, T. Douglas, C.M. Lawrence, Structure of the Dps-like protein from Sulfolobus solfataricus reveals a bacterioferritin-like dimetal binding site within a Dps-like dodecameric assembly, Biochemistry 45 (2006) 10815-10827, http://10.1021/bi060782u.

[15] M. Bozzi, G. Mignogna, S. Stefanini, D. Barra, C. Longhi, P. Valenti, E. Chiancone, A novel non-heme iron-binding ferritin related to the DNA binding proteins of the Dps family in Listeria innocua, J. Biol. Chem. 272 (1997) 3259-3265, http://10.1074/ jbc.272.6.3259.

[16] S.C. Gill, P.H. von Hippel, Calculation of protein extinction coefficients from amino acid sequence data, Anal. Biochem. 182 (1989) 319-326, http://10.1016/00032697(89)90602-7.

[17] Z. Otwinowski, W. Minor, Processing of X-ray diffraction data collected in oscillation mode, Methods Enzymol. 276 (1997) 307-326, http://10.1016/S00766879(97)76066-X.

[18] A. Vagin, A. Teplyakov, Molecular replacement with MOLREP, Acta Crystallogr. Sect. D: Biol. Crystallogr. 66 (2010) 22-25, http://10.1107/S0907444909042589.

[19] M.D. Winn, G.N. Murshudov, M.Z. Papiz, Macromolecular TLS refinement in REFMAC at moderate resolutions, Methods Enzymol. 374 (2003) 300-321, http://10.1016/S0076-6879(03)74014-2.

[20] P. Emsley, K. Cowtan, COOT: model-building tools for molecular graphics, Acta Crystallogr. Sect. D: Biol. Crystallogr. D60 (2004) 2126-2132, http://10.1107/ S0907444904019158.

[21] S. Solar, N. Getof, S. Parminder, D.A. Armstrong, A. Singh, Oxidation of tryptophan and $\mathrm{N}$-methylindole by $\mathrm{N}_{3} \cdot \mathrm{Br}_{2}{ }^{\bullet-}$, and $(\mathrm{SCN})_{2} \cdot-$ radicals in light- and heavywater solutions: a pulse radiolysis study, J. Phys. Chem. 95 (1991) 3639-3643, http://10.1021/j100162a038.

[22] S. Roy, R. Saraswathi, D. Chatterji, M. Vijayan, Structural studies on the second Mycobacterium smegmatis Dps invariant and variable features of structure, assembly and function, J. Mol. Biol. 25 (2008) 948-959, http://10.1016/j.jmb.2007.10.023.

[23] A. Ilari, S. Stefanini, E. Chiancone, D. Tsernoglou, The dodecameric ferritin from Listeria innocua contains a novel intersubunit iron-binding site, Nat. Struct. Mol. Biol. 7 (2000) 38-43, http://10.1038/71236.

[24] P. Ceci, G. Di Cecca, M. Falconi, F. Oteri, C. Zamparelli, E. Chiancone, Effect of the charge distribution along the "ferritin-like" pores of the proteins from the Dps family on the iron incorporation process, J. Biol. Inorg. Chem. 16 (2011) 869-880, http://10.1007/s00775-011-0784-9.

[25] S. Stefanini, P. Ceci, M. Ardini, A. Ilari, DNA-binding proteins from starved cells (Dps proteins), in: A. Messerschmidt (Ed.), Handbook of Metalloproteins, J. Wiley \& Sons, Chichester (UK), 2010, pp. 1-10, http://10.1002/0470028637.met258.

[26] E. Chiancone, P. Ceci, The multifaceted capacity of Dps proteins to combat bacterial stress conditions. Detoxification of iron and hydrogen peroxide and DNA binding, Biochim. Biophys. Acta 1800 (2010) 798-805, http://10.1016/j.bbagen. 2010.01.013.

[27] M.G. Cuypers, E.P. Mitchell, C.V. Romão, S.M. McSweney, The crystal structure of the Dps from Deinococcus radiodurans reveals an unusual pore profile with a non-specific metal binding site, J. Mol. Biol. 371 (2007) 789-799, http://10.1016 j.jmb.2006.11.032.

[28] B. Ren, G. Tibbelin, T. Kajino, O. Asami, R. Ladenstein, The multi-layered structure of Dps with a novel di-nuclear ferroxidase center, J. Mol. Biol. 329 (2003) 467-477, http://10.1016/S0022-2836(03)00466-2. 
[29] R.A. Grant, D.J. Filman, S.E. Finkel, R. Kolter, J.M. Hogle, The crystal structure of Dps, a ferritin homolog that binds and protects DNA, Nat. Struct. Mol. Biol. 5 (1998) 294-303, http://10.1038/nsb0498-294.

[30] S. Franceschini, P. Ceci, F. Alaleona, E. Chiancone, A. Ilari, Antioxidant Dps protein from the thermophilic cyanobacterium Thermosynechococcus elongatus, FEBS J. 273 (2006) 4913-4928, http://10.1111/j.1742-4658.2006.05490.x.

[31] F. Alaleona, S. Franceschini, P. Ceci, A. Ilari, E. Chiancone, Thermosynechoccus elongatus DpsA binds $\mathrm{Zn}$ (II) at a unique three histidine-containing ferroxidase center and utilizes $\mathrm{O}_{2}$ as iron oxidant with very high efficiency, unlike the typical Dps proteins, FEBS J. 277 (2010) 903-917, http://10.1111/j.1742-4658.2009.07532.x.

[32] S.G. Kim, G. Bhattacharyya, A. Grove, Y.H. Lee, Crystal structure of Dps-1, a functionally distinct Dps protein from Deinococcus radiodurans, J. Mol. Biol. 361 (2006) 105-114, http://10.1016/j.jmb.2006.06.010.

[33] T.J. Stilman, M. Upadhyay, V.A. Norte, S.E. Sedelnikova, M. Carradus, S. Tzokov, P.A. Bullough, C.A. Shearman, M.J. Gasson, C.H. Williams, P.J. Artymiuk, J. Green, The crystal structures of Lactococcus lactis MG1363 Dps proteins reveal the presence of an N-terminal helix that is required for DNA binding, Mol. Microbiol. 57 (2005) 1101-1112, http://10.1111/j.1365-2958.2005.04757.x.

[34] A. Kauko, S. Haataja, A.T. Pulliainen, J. Finne, A.C. Papageorgiou, Crystal structure of Streptococcus suis Dps-like peroxide resistance protein Dpr: implications for iron incorporation, J. Mol. Biol. 338 (2004) 547-558, http://10.1016/j.jmb.2004. 03.009.
[35] T. Haikarainen, A. Thanassoulas, P. Stavros, G. Nounesis, S. Haataja, A.C. Papageorgiou, Structural and thermodynamic characterization of metal ion binding in Streptococcus suis Dpr, J. Mol. Biol. 405 (2011) 448-460, http://10.1016/j.jmb.2010.10.058.

[36] M. Su, S. Cavallo, S. Stefanini, E. Chiancone, N.D. Chasteen, The so-called Listeria innocua ferritin is a Dps protein. Iron incorporation, detoxification, and DNA protection properties, Biochemistry 44 (2005) 5572-5578, http://10.1021/ bi0472705.

[37] J.A. Hayden, M.P. Hendrich, EPR spectroscopy and catalase activity of manganesebound DNA-binding protein from nutrient starved cells, J. Biol. Inorg. Chem. 15 (2010) 729-736, http://10.1007/s00775-010-0640-3.

[38] G. Bellapadrona, M. Ardini, P. Ceci, S. Stefanini, E. Chiancone, Dps proteins prevent Fenton-mediated oxidative damage by trapping hydroxyl radicals within the protein shell, Free Radic. Biol. Med. 48 (2010) 292-297, http://10.1016/j.freeradbiomed. 2009.10.053.

[39] A.K. Boal, J.A. Cotruvo Jr. J. Stubbe, A.C. Rosenzweig Structural basis for activation of class Ib ribonucleotide reductase, Science 329 (2010) 1526-1530, http://10.1126/ science. 1190187.

[40] W.L. DeLano, The PyMOL Molecular Graphics System, DeLano Scientific, San Carlos (CA), 2002.

[41] G. Zhao, P. Ceci, A. Ilari, L. Giangiacomo, T.M. Laue, E. Chiancone, N.D. Chasteen, Iron and hydrogen peroxide detoxification properties of DNA-binding protein from starved cells, J. Biol. Chem. 277 (2002) 27689-27696, http://10.1074/j be.M202094200. 